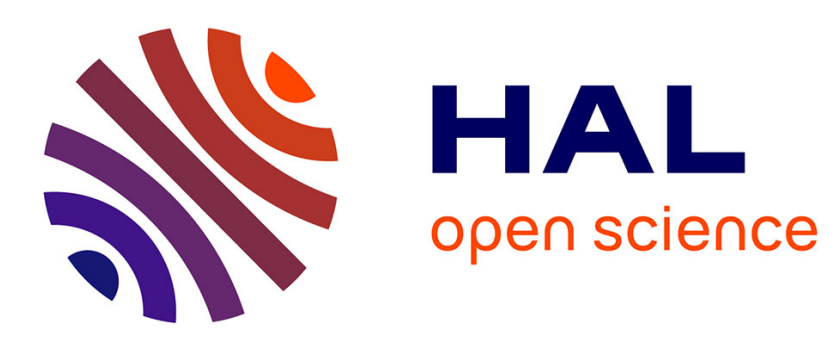

\title{
Technological competition: a path towards commoditization or differentiation? Some evidence from a comparison of e-book readers
}

\author{
Pierre-Jean Benghozi, Elisa Salvador
}

\section{- To cite this version:}

Pierre-Jean Benghozi, Elisa Salvador. Technological competition: a path towards commoditization or differentiation? Some evidence from a comparison of e-book readers. Systèmes d'Information et Management, 2015, 20 (3), pp.97 - 135. hal-02080207

\section{HAL Id: hal-02080207 https://hal.science/hal-02080207}

Submitted on 26 Mar 2019

HAL is a multi-disciplinary open access archive for the deposit and dissemination of scientific research documents, whether they are published or not. The documents may come from teaching and research institutions in France or abroad, or from public or private research centers.
L'archive ouverte pluridisciplinaire HAL, est destinée au dépôt et à la diffusion de documents scientifiques de niveau recherche, publiés ou non, émanant des établissements d'enseignement et de recherche français ou étrangers, des laboratoires publics ou privés. 
This article has been accepted for publication by the Journal

Systèmes d'Information et Management

It can be cited as follows:

Benghozi P.-J., Salvador E. (2015) "Technological competition: a path towards commoditization or differentiation? Some evidence from a comparison of e-book readers", Systèmes d'Information et Management (SIM), vol. 20, n. 3, pp. 97-135.

\title{
Technological competition: a path towards commoditization or differentiation? Some evidence from a comparison of e-book readers
}

\author{
Pierre-Jean Benghozi* \\ Elisa Salvador** \\ * I3-CRG, Ecole Polytechnique, Paris, France \\ ** I3-CRG, Ecole Polytechnique, Paris, France and Iéseg School of Management, \\ Paris campus, France
}

\begin{abstract}
Technological rivalry is recognized as a key dimension of competition and innovation strategies in the digital era. It is particularly important in strategies focused on disruptive and repeated innovations, where each step contributes to shaping the design of the offering, the structuring of the market and the value chain. These technological trajectories are built on the basis of tensions between two contradictory objectives: specialization aimed at creating proprietary systems and standardization aimed at supplying the overall market. In the former case, successive innovations support competition between exclusive and proprietary ecosystems. In the latter case, commoditized devices create opportunities for alternative actors to engage in innovation and value creation. The e-book reader market serves as a key example of the issues at stake in terms of technological rivalry among technology suppliers, digital platforms, and publishers.
\end{abstract}

Keywords: creative industry; book- publishing industry; business model; e-book; repeated innovation

Acknowledgements: The research has been made possible by the financial support of the Centre National du Livre (CNL), Paris. 


\title{
« Concurrence technologique: facteur de commoditisation ou de différenciation? Les leçons des liseuses de livre numérique »
}

\author{
* Pierre-Jean Benghozi \\ ** Elisa Salvador \\ * I3-CRG, Ecole Polytechnique, Paris, France, \\ ** I3-CRG, Ecole Polytechnique, Paris, France and Iéseg School of Management, \\ Paris campus
}

\begin{abstract}
Résumé:
La concurrence par la technologie est au cœur des dynamiques compétitives du numérique. Elle se traduit par des stratégies industrielles articulant innovations de rupture et innovations répétées et façonnant progressivement, au fil d'étapes successives, la configuration des offres, la structure des marchés et l'organisation des filières industrielles. Ces trajectoires technologiques résultent de tensions entre deux objectifs contradictoires : se spécialiser sur des systèmes propriétaires pour mieux maîtriser une base de clients, ou s'inscrire dans des standards partagés pour pouvoir adresser l'ensemble du marché. Dans un cas, la succession d'innovations consolide une concurrence entre écosystèmes propriétaires et exclusifs ; dans 1'autre cas, les perspectives d'innovation et de création de valeur s'ouvrent plus largement à tous les acteurs des filières car elles s'appuient sur des supports technologiques « commoditisés ». Le marché des liseuses offre une illustration emblématique de ces enjeux qui se jouent, dans la concurrence technologique, entre fournisseurs de terminaux, plateformes numérique et éditeurs.
\end{abstract}

Mots-clés: industries créatives ; industrie de l'édition du livre ; modèles d'affaires ; livre numérique ; innovation répétée 


\section{Introduction}

The importance of technological rivalry, platforms, and articulation in disruptive, incremental, and repeated innovations is an essential element of recent research on innovation in the digital era. This is particularly true in the information and communication technology (ICT) sector owing to the opportunities created by information technologies and the Internet for preconfiguring offerings and creating disruptive changes in usage on the market. Deltour and Lethiais (2014), for instance, recently highlighted that ICTs contribute to improvements in performance when they support innovation, showing that performance is positively influenced by SMEs' innovativeness when accompanied by specific investments in ICTs or by more intense use of existing ICTs. Furthermore, the particular nature of ICT generates specific articulations among infrastructures, software, and terminals due to programming languages, interoperability interfaces, and proprietary standards (Lessig, 2006).

These technological trajectories are built on the basis of tensions between two contradictory objectives: specialization aimed at building proprietary systems or, at least, at capturing the essential value of proprietary systems; and standardization that focuses on the value made available to the entire market. In the former case, repeated innovations support the competition between exclusive and proprietary ecosystems. In the latter case, commoditized devices create opportunities for alternative actors to engage in innovation and value creation.

In this context, the development of devices that make it possible to read a book in electronic or digital form (e-book readers) is particularly interesting because it clearly illustrates the steps in building technological trajectories, as well as the ways in which relationships between content and technology offerings are established. The e-book reader market serves as a key example of the issues at stake in terms of technological rivalry among technology suppliers, digital platforms, and publishers. The case shows that a focus on specialization or standardization involves different technological-development paths that take the form of the deepening proprietary standards (thanks to consecutive, repeated innovations) or of convergent innovations aimed at commoditization, respectively.

The literature on innovation demonstrates that such trajectories traditionally serve as strategic alternatives for technological rivalries. One may view innovation strategies as the result of a progressive process resulting from the sequence of probing cycles and tested in the same technological trajectory. This is the perspective of those authors who have developed the theory of dynamic capabilities (Teece et al., 1997; Brown \& Einsenhardt, 1998; Thomke, 1998; Von Hippel, 2005; Schreyögg \& Kliesch-Eberl, 2007). A series of innovations can also be viewed as the result of modular product design. New developments create "windows of opportunity" (Tyre \& Orlikowski, 1994) that will be closed when the structural choices have been made, which in turn pave the way for incremental innovations. Sanchez and Mahoney (1996) provide one example taken from the automobile industry. In all cases, strategic innovations help to not only define business models for which the rules have been changed but also to reinvent the nature of the competition (Hamel, 1998; Markides, 1998; Schlegelmilch et al., 2003).

The e-reader market shows that platforms play very different roles in the rivalry among technological trajectories (Benghozi \& Salvador, 2014). As Gawer (2009) points out, the structuring and economics of platforms has become a dominant model that is evident in all innovative and cultural sectors. Consequently, the content itself as well as the way of presenting that content play key roles. The different ways in which the content of a platform is presented are primarily determined by the technology used. Platform leaders establish successful products, services, or technologies, which become the industrial technological basis adopted by other supply companies (Gawer \& Cusumano, 2002). Platform offerings may also include complementary products. This fosters network externalities and increases the global value of the platform. Consequently, disruptive and incremental innovations contribute to the renovation of the overall process and to the structuring of a specific ecosystem (Benghozi, 2014). In other 
words, platforms not only promote the development of industrial ecosystems, but they also transform the economics and concurrence of the linked sectors. The emergence of new offerings, new business models, and new actors are some examples of this transformation. Platforms centered on cultural content, like Amazon, are strengthened by their capacity to attract new clients interested in the content, and by their ability to valorize the group of clients created and their personal data. This process combines the exploitation of two strategic resources: the potential to address a two-sided market (Rochet \& Tirole, 2003) and the value of network externalities (Katz \& Shapiro, 1986). As such, it leads to coopetition processes: technological trajectories are led by those platform leaders that establish unique partnerships in order to strengthen their control over the market. The dependence on other companies in the ecosystem for building value and feeding the ecosystem as a whole implies that the competition among platforms takes the place of competition among traditional economic actors.

While this competition among platforms is well documented in the literature, little is known about how it is operationalized in the management of digital technologies. Along these lines, the introduction of e-books serves as a good example of how ICTs are transforming the competitive structure of an industrial sector. This new technology has clearly affected growth in the book-publishing business of and altered the phases of the traditional value chain in the publishing sector (Benghozi \& Salvador, 2015). New tools - e-book readers - have appeared and new actors, such as technology suppliers, have become active in the market. As a consequence, fierce competition among enterprises producing e-book readers has emerged in recent years. Since the very first versions of the Sony and Kindle e-readers appeared on the market in 2006 and 2007, several other actors have begun to offer alternatives. R\&D and innovation technologies appear to be at the core of the competition process. Leading-edge technologies related to inks, displays, screens, light, quality of image, battery life, sound, and ergonomics are some key aspects of this ongoing revolution. In addition, the rivalry (Miller, 2013) is motivating e-book producers to innovate so as not to lose market shares. Even though one of the main consequences of this rivalry is a general decline in prices, $R \& D$ and innovation continue.

In this article, we analyze the e-book reader market. We argue that technology suppliers, digitalplatform developers, and publishers are involved in the technological rivalry, which is supported by repeated innovations that contribute to consolidating and reinforcing legacy systems (Hatchuel \& Le Masson, 2006). In addition, we find evidence of coopetition in terms of the development or adaptation of disruptive standards (Brandenburger \& Nalebuff, 1996; Ritala, 2012; Bouncken \& Fredrich, 2012; Ritala \& Hurmelinna-Laukkanen, 2013; Ritala \& Sainio, 2014), coevolution in various technological layers (Sotarauta \& Srinivas, 2005), and imitation aimed at compensating for a lack of investment and strategic vision (Hannan, 2005; Hannan et al., 2006; Aldrich \& Ruef, 2006). The goal of our analysis is to show that technological trajectories in the digital age demonstrate the existence of alternative strategies of standardization or specialization, or convergence or differentiation, and that they are therefore the reflection of competitive positions on the market. In other words, we aim to highlight how these technological trajectories foster movements towards convergence or differentiation, which illustrate standardization or specialization, respectively.

To the best of our knowledge, complete analyses of the evolution in technological trajectories for the leading e-readers do not exist. A significant amount of literature compares the features of printed books with those of e-books (see, among others, Park et al., 2010; Dacos \& Mounier, 2010; OECD, 2012), but longitudinal analyses of the technological evolution of all versions of the "star" e-readers that have been released over the years are not available. The rapid evolution characterizing the Internet and the ICT world is one of the main constraints in this regard. Another is the difficulty of creating clarity in a complex, confusing context in which a single leader is not identifiable but various actors all lead the market in some way. Amazon's Kindle 
holds a dominant position in the e-books market, but many other e-reader producers are competing on the same level (Miller, 2013; MarketLine, 2013).

In a nutshell, we examine how microeconomic strategic behaviors contribute in the long term to momentous technological trajectories and market structures. More specifically, we investigate the extent to which technological innovations in e-readers reflect competitive positioning strategies that help define the long-term trajectories of technological convergence or differentiation. For this purpose, we use a combination of comparative case studies and quantitative analysis (Eisenhardt, 1989; Eisenhardt \& Graebner, 2007; Siggelkow, 2007; Ragin \& Amoroso, 2011). Our basic idea is to characterize the comparative technical trajectories in order to understand the components in which various economic actors invest, the evolution of each rhythm, and the resulting dynamic.

This is the approach we adopt in this article - the identification of the e-reader producers that lead the market and the analysis of the characteristics of the various versions of their devices. This enables us to reconstruct the technological-evolution path followed by these actors and to uncover the strategy based on dynamic moves of various types: repeated innovation, coopetition, coevolution, and imitation. We do not deny the emergence of and recent competition from tablets, such as the iPad. However, the purpose of this paper is to provide a comparative analysis of the technological trajectories of e-readers. Therefore, comparisons with tablets are only introduced in the discussion of the results.

A matrix of the technological trajectories of all versions of six key brands of e-readers active on the market is used to characterize the evolution of R\&D and innovation in this field. Kindle, the most known and cited e-reader, is most often compared with Nook, Kobo and Sony ${ }^{1}$ (Miller, 2013; MarketLine, 2013). Furthermore, we wanted to compare the large international suppliers with a dominant player in a national market. For this reason, we added Bookeen, the best known French e-reader, to our list. As we also wanted to compare the incumbents with emerging actors, we included Pocketbook, a rising East European e-reader that has entered into an alliance with the French company TEA. TEA specializes in open software solutions for selling and reading e-books. Several specific strategies and trajectories characterizing the six enterprises' development towards a path of convergence or divergence are identified.

The article is structured as follows. The theoretical framework focuses on technological rivalries from disruptive innovation (Christensen, 1997) to repeated innovation, coopetition, coevolution, and imitation, with a focus on actual competition in the e-book reader market. The methodology applied and the results of the analysis follow thereafter, and the evolution of the main technical characteristics of all versions of the producers' "star" leaders on the market is described. A discussion of our results, as well as some limitations and conclusions, is presented in the final section.

\section{Theoretical framework}

Technological rivalry in the areas of ICT, software, and the service industry has been studied in many interesting articles. This research has, inter alia, analyzed the characteristics of open and modular systems ${ }^{2}$ based on conventional, agreed-upon, and shared knowledge of software development, and, on the other side, closed, packaged ${ }^{3}$ systems based on purposeful strategies adopted by major players to gain a competitive advantage (Fitzgerald, 2006). Fitzgerald (2006) highlights that the former has a very strong commercial orientation with a deep emphasis on

\footnotetext{
${ }^{1}$ Google searches for the "best known" or "best sold" e-readers confirm that Kindle, Nook, Kobo and Sony are the most cited e-readers. These e-readers are also those usually compared on price-comparison sites.

2 "Free/Libre/Open Source Software (FLOSS) is software the user can use for any purpose, study its source code, adapt it to his needs, and redistribute - modified or unmodified" (Vitari \& Ravarini, 2009, p. 251).

3 "Packaged software is commercially available software, where the user has no free access to the source code and no rights to redistribute” (Vitari \& Ravarini, 2009, p. 251).
} 
services. Moreover, it alters the basic rules of the software industry: the proprietary-driven model disappears. More sophisticated business models are emerging. Furthermore, "companies can also leverage the commodification effect that has occurred with open source. They take advantage of open source in terms of its low cost, reliability, and portability across platforms" (Fitzgerald, 2006, p. 592).

In line with McGahan's (2004) industry change trajectory theory, ${ }^{4}$ Vitari and Ravarini (2009) suggest that the industry is constantly redeveloping its assets - its software applications and the supporting hardware. It follows a creative-change trajectory because core software-industry activities are not believed to be threatened by rapid obsolescence. Nonetheless, some research indicates that recent changes may have an impact on the industrial change trajectory in the form of a shift towards commoditization. Commoditization ${ }^{5}$ can be defined as the process by which a product loses all of its specific attributes, such that is no longer truly distinguishable by customers. As a consequence, customers make consumption decisions mainly on the basis of price. Reimann et al. (2010, p. 189) argue that "industry commoditization describes an increase in similarity between the offerings of competitors in an industry, an increase in customers' price sensitivity, a decrease in customers' cost of switching from one to another supplier in an industry, and an increase in the stability of the competitive structure". Furthermore, Carr (2004) stresses a fundamental trend: new technologies tend to become standardized, increasingly identical, and indistinguishable. Consequently, these technologies do not provide the firms that adopt them with any competitive advantage. Information technology has been transformed from a strategic resource into a commodity input: the cost of doing business is paid by all but no one entity is truly distinguishable. ${ }^{6}$

Piccoli and Lui (2014) recently tested the propositions that information technology is a commodity and that IT-enabled resources engender a sustained competitive advantage. They proposed that IT-dependent strategic initiatives have the potential to generate sustained competitive performance, even when the technologies that enable them appear "simple". These authors suggest that their findings call for a theoretical explanation of the complementarities and interactions among the various elements of IT-dependent strategic initiatives.

Vitari and Ravarini (2009) highlight such interactions between cost reduction and the increase in the number of available functions in their analysis of content-management systems (CMS). This dynamic points to the effects of technological competition in an ICT-based industry facing a declining cost-to-performance ratio for IT assets over time, which creates cost disadvantages for early entrants. Consequently, the differentiation strategy chosen by packaged CMS relative to free open-source software (OSS) CMS consists of developing a wider services offering. According to Vitari and Ravarini (2009), the evolution of the CMS segment does not follow a creative-change trajectory but a radical one. Therefore, CMS organizations are forced to gradually change their strategies by abandoning unprofitable activities and expanding profitable ones.

Similar developments and technological rivalries are also evident in other ICT-supported sectors. Cecere et al. (2015) focus on the emergence of smartphones with similar characteristics in the mobile-communication sector. The introduction of a series of intangible (operating systems) and tangible (hardware) technological changes characterizes this sector. The authors highlight that the iPhone disrupted the traditional market by integrating a new phone with a

\footnotetext{
4 McGahan (2004) proposes four main trajectories of industry change (radical, progressive, creative and intermediating) and two threats of obsolescence (of core activities or of core assets).

${ }^{5}$ For a detailed review of the literature about commoditization, see Chamaret (2012).

6 “IT's transformation from a set of proprietary and heterogeneous systems into a shared and standardized infrastructure is a natural, necessary and healthy process. It is only by becoming an infrastructure - a common resource - that IT can deliver its greatest economic and social benefits" (Carr, 2004, p. xiv).
} 
mobile-phone operating system, an Internet browser, and the iTunes Store for downloading audio and video files. A similar disruptive innovation emerged in the traditional book industry with the arrival of the e-book and several e-reader producers.

In this context, the technological and digital revolution brought on by the Internet and ICTs is deeply affecting the economics of a certain sector - the book-publishing industry. The secular model of the printed book has been confronted with the emerging diffusion of e-books. The impact is so strong that effective business models for the e-book market are still missing (Riot, 2013; Miller, 2013; Simon, 2014). Moreover, several e-book readers have taken the position of "star" leaders, but their positions may be temporary.

In order to understand the characteristics of the technological rivalry between the most important e-reader producers and the recent evolution of that rivalry, the following sections provide some insights into the concept of technological rivalry, as well as the historical context of the book-publishing industry.

\subsection{Technological rivalry and growth: from disruptive innovation to a strategy of repeated innovation, coopetition, coevolution, and imitation}

The concept of repeated innovation is an alternative to various forms of incremental innovation and disruptive innovation. In line with the seminal contribution of Christensen (1997), "disruptive innovation" usually refers to new technologies or services that provide original solutions that are radically different from the existing dominant products or services. Moreover, it follows a different trajectory from mainstream market technologies. New entrants can replace large incumbents thanks to a disruptive, more affordable technology that improves in quality over time and gains market share from established companies. Operational innovation ${ }^{7}$ is one form of innovation that is disruptive in nature (David, 1985; Benghozi, 1990; Hammer, 2004). Recent investigations have attempted to complement the seminal definition (Habtay, 2012; Klenner et al., 2013) by taking into account such aspects as the geographical dimension of disruptive innovation (Corsi \& Di Minin, 2014), company size (disruptive strategies are also feasible options for small and medium-sized innovative companies; Dumoulin \& Simon, 2005), or the importance of spin-off companies as a solution to the innovator's dilemma (Christensen \& Raynor, 2003). According to Chandra and Yang (2012, p. 25), a disruptive innovation may be identified when "a new product (including service, process and business model) replaces the existing dominant design with exceptional commercial success", meaning that technological success is strictly linked to market success. Furthermore, design-driven innovation enhances the likelihood of generating disruptive products - this was the case with Apple's iPhone 4 (Cecere et al., 2015). Apple's attention to design was linked to the use of a network of external applications developed to respond to most user needs. Other examples, like Google and Facebook, highlight another aspect that may lead to disruptive innovation: powerful algorithms for effective searching on the Internet and the introduction of competence-destroying innovations enabled these websites to make themselves the leading sites in their respective fields (Chandra \& Yang, 2012).

$\mathrm{Yu}$ and Hang (2010) remind us that disruptive innovations do not necessarily imply a replacement of incumbents or traditional businesses, and that disruptors are not always startups. An incumbent business with existing high-end technologies can survive by focusing on dedicated customers and a niche market. A classic example is found in Sony's success with the Walkman. In other words, incumbents may survive a disruptive innovation or even play the role of a smart disruptor. A small or medium-sized company will not be able to introduce many disruptive innovations because of a lack of financing and creativity. Consequently, company resources will most likely be dedicated to protecting the new business model, and to valorizing

\footnotetext{
7 "Operational innovation means coming up with entirely new ways of filling orders, developing products,
} providing customer service, or doing any other activity that an enterprise performs" (Hammer, 2004, p. 86). 
one or two disruptive innovations. This can be viewed as a key step in the company's development because a disruptive innovation upsets internal processes and organization (Dumoulin \& Simon, 2005).

From this perspective, repeated innovation may be seen as an alternative to disruptive innovations. Hatchuel and Le Masson (2006) focus on how firms grow through repeated innovation. These authors stress that rather than focusing on a single isolated innovation that may not ensure long-lasting success, it might be better for a firm to maintain a sustained rate of innovation and, thereby, produce a chain of repeated innovations. Constant product renewals through continual changes, diversification, and design improvements may be a good strategic choice for innovation policy over the long term.

This is exactly what has occurred in recent years in the e-book reader market: the organization and management of a permanent program of minor but significant innovations. In their case study of Tefal, Hatchuel and Le Masson (2006, p. 2) define this strategy as a "truly original management model", underlining that "the model of growth by innovation provides a higher probability of survival over the long term", even if that model is not dominant. Of course, an ability to innovate is required in order to develop the business of innovation. Therefore, an "invention factory" is an essential element.

The series of steady innovations evident in the e-reader market seems to follow the strategy of repeated innovation through the adoption of an invention factory. This strategic adoption is a condition sine qua non for survival in this rapidly evolving market, in which business models are not well-defined, and new competitors are constantly appearing.

According to Hatchuel et al. (2001, p. 7), "the necessity to 'repeat innovation' creates a need for both stability and change". Innovation is considered a specific management process, and an innovative firm is "a firm that is able to maintain a persistent and repeated flow of innovations". In fact, this process of repeated innovation must be consolidated through R\&D activities that enable the structuring choices essential for building lineages of products and competencies. Any excess knowledge may be used by the firm for introducing innovative products at a later point in time.

Furthermore, the concept of repeated innovation highlights a new approach in the technological trajectory usually followed by firms. This approach combines technical and market-based trajectories through a sequence of successive innovations, which involve creativity, strategic decision making, and various learning processes. This approach reflects the fact that learning rents do not last forever - temporary monopolies may be attacked by competitors. As a consequence, successive products that ensure the firm's long-term survival serve to ensure the firm's competitive position. Innovation on a continual basis along the same technological path contributes to strengthening the firm's technological knowledge and resources, to consolidating the customer base, and to enhancing market positioning.

The concept of repeated innovation is closely related to coopetitive strategies and the relevance of network externalities for increasing firms' performance (see Ritala \& HurmelinnaLaukkanen, 2009; Ritala, 2012; Bouncken \& Fredrich, 2012). In game theory, coopetition is referred to a phenomenon of simultaneous and mutual competition and collaboration between complementary firms that cooperate while remaining competitors (Brandenburger \& Nalebuff, 1996). On the basis of this seminal definition, researchers have set off in several disparate directions (Yami et al., 2010). Nonetheless, following the Internet and ICT revolution, simultaneous cooperation-collaboration now includes the ability to integrate external resources through networking as well as more dynamic and/or contradictory interactions. It has therefore become a common practice in high-technology industries and knowledge-intensive sectors owing to their networked nature (Ritala, 2012; Ritala \& Sainio, 2014). In general, firm-specific capabilities are important for coopetition success (Ritala \& Hurmelinna-Laukkanen, 2013). For example, the coopetition between Sony and Samsung in the LCD TV market resulted in 
worldwide success. The complementary resources found in Sony's superior technological know-how and Samsung's marketing abilities enabled that success (Ritala et al., 2014). Bengtsson and Kock (2014, p. 180) recently suggested that "coopetition is a paradoxical relationship between two or more actors, regardless of whether they are in horizontal or vertical relationships, simultaneously involved in cooperative and competitive interactions". As such, coopetition is not restricted to a relationship between two firms, as many firms may be simultaneously involved in this process, and the related coopetition strategies may affect market performance (Le Roy \& Sanou, 2014).

Moreover, coopetition is often linked to innovation, as coopetitive activities may increase firms' innovativeness (Bengtsson \& Kock, 2014) and advance their technological innovation (Gnyawali \& Park, 2011). In particular, Ritala (2012) suggests that a technology or a solution may be too risky for a single firm because time and speed are critical factors in ICT, and the necessary knowledge becomes rapidly outdated. Therefore, the building of strategic alliances with competitors may represent an interesting option. Obviously, the paradoxical nature of coopetition may result in tensions at the individual, organizational, and inter-organizational levels, and in changes in coopetitive interactions over time (Raza-Ullah et al., 2014; Dahl, 2014). Bouncken and Fredrich (2012) argue that coopetition can increase firms' radical innovation in the IT sector by providing them with key complementary assets for radical innovation that are otherwise difficult to obtain. In a comparison of radical and incremental innovation, these authors find that coopetition is more beneficial for radical innovation than for incremental innovation. However, in order to be able to innovate repeatedly along the same path while limiting their risks, firms have to cooperate and collaborate with their competitors (Hamel et al., 1989) to develop common standards and platforms. In other words, they must collectively agree on the technological "rules of the game". This might explain why enterprises are motivated to cooperate and share resources with the same economic actors with which they are competing (Brandenburger \& Nalebuff, 1996; Chalant \& Lecloux, 2010). Such a coopetition approach can be identified in the similar strategies adopted by the e-reader producers. They seem to implicitly cooperate in order to realize a common and convergent goal of creating value through a competitive advantage. Cooperation and competition are interdependent, and both are present.

This process is also linked to business-model choices (Benghozi \& Paris, 2007; Teece, 2010; Lyubareva et al., 2013; Ritala et al., 2014), which help determine technological trajectories. Recently, Ritala and Sainio (2014) showed that coopetition is positively related to businessmodel radicalness, meaning that coopetition is likely to promote the emergence of radical business-model innovations due to the competitors' willingness to differentiate their offerings. Ritala et al. (2014) analyze the role of coopetition in the overall business model of Amazon.com. As a customer-centric company, Amazon uses strategic coopetition as a way to create more customer value. This strategy has enabled Amazon to become a worldwide leader in media and web services. Baden-Fuller and Haefliger (2013) propose that although technological development may facilitate the emergence of new business models, it is not an essential prerequisite for business-model innovation. Interactions between business models and technologies are usually observed. In this regard, Baden-Fuller and Haefliger (2013, p. 419) also cite the example of Amazon: "When Amazon was founded in 1995, they applied new technology to make the traditional mail-order business model pioneered by Sears Roebuck work well for books. Amazon did not invent a new business model". Instead, it applied a version of a well-known model to a new context. In recent years, we have observed more intense, dynamic, and uncertain interoperability between technologies owing to the emergence of sophisticated ICTs and the wider availability of platform technologies (Baden-Fuller \& Haefliger, 2013). Repeated innovation and coopetition also lead to a process of coevolution and reciprocal imitation. According to Sotarauta and Srinivas (2005, p. 20), "on the general level, we see co- 
evolution taking place if two or more agents and/or their environments influence each other's selection and/or retention processes and if a series of variations takes place in time in the respective agents. If an agent is merely responding to another agent's presence or activities by adaptation, we do not see that as co-evolution, because according to our understanding, coevolution consists of a series of responses and can therefore be seen as a reciprocally induced evolutionary change between two or more agents and their environment in time (Lewin, Volberda, 1999; Murmann, 2003; Volberda, Lewin, 2003)". Ritala and Hurmelinna-Laukkanen (2013, p. 157) discuss protection from imitation, especially in coopetitive relationships: "To keep their leading competitive position and to reap the benefits of innovation, best-practice firms need to create obstacles to imitation. This is particularly crucial for firms that have engaged in coopetition: their knowledge bases are already relatively close to each other, and thus not only the threat of imitation but also the likelihood of it taking place are high (in the sense that the competitor is willing to learn from the firm and to utilize such knowledge in competition)".

The different phases of the process described here help us to understand, identify, and explain the various successive steps in the technological evolution of e-book readers. The important role played by $R \& D$ in the digital world - especially in terms of the need for significant investments and sharp competences, and the presence of complex ecosystems - induces companies to adopt coopetition behaviors. This phenomenon reinforces imitation behaviors, and attributes importance to components and technological platforms common to e-readers (e.g., screens, smart chips). As such, they are commoditization factors. Otherwise, the composite nature of devices means that innovations in this sector are the result of several technical registers. As a consequence, e-readers start from a common technological platform, and are then subject to successive and/or repeated innovations that enable economic actors to differentiate their devices. The key is to understand how these steps are operationalized in innovations and technological developments.

\subsection{A brief overview of the history of the book-publishing industry and the emergence of the e-book revolution}

The Internet and ICT revolution brought significant changes to the book-publishing sector. While the cinema and the music sectors suffered from several rapid changes over the years (Blanc \& Huault, 2014; Ruling \& Duymedjian, 2014), the publishing industry was influenced by the digital revolution at a later point and with a less severe impact (Benhamou, 2014). Nonetheless, this slow technological revolution has had an unusual, disruptive, and radical impact on the traditional, low-growth book-publishing industry (Ronte, 2001; OECD, 2012; Simon, 2014).

The book-publishing industry is the oldest subsector in the media and content industries. It dates back to the introduction of the codex (the format used for modern books) around the first century A.D. That format is viewed as the most important technological development prior to the invention of steam-powered printing presses at the beginning of the nineteenth century (Simon \& de Prato, 2012).

Michael Hart, the founder of Project Gutenberg ${ }^{8}$, created the very first e-book and digital library in 1971 (Lebert, 2009). Since then, the main dimension of book evolution has been digitalization - the evolution from books on paper to books in digital form (Park et al., 2010; Dacos \& Mounier, 2010; OECD, 2012). Several studies have analyzed various aspects of ebook history (see Hsieh et al., 2011). In recent years, numerous contributions have also investigated the transformations in the publishing industry resulting from the emergence of the

\footnotetext{
8 "Project Gutenberg is a volunteer effort to digitize and archive cultural works, to 'encourage the creation and distribution of e-books'... it was the world's first digital library. Most of the items in its collection are the full texts of public domain books" (OECD, 2012, p. 38).
} 
e-book model. While some authors focus on the history of books (Howard, 2009) or the history of e-books (Lebert, 2009), others investigate e-books in relation to a specific country, such as France (Dacos \& Mounier, 2010; Rouet, 2007) or the US (Greco, 2005, 2011).

According to Ronte (2001, p. 12), "technology is changing the rules of the game. A low-growth market implies that technology creates incremental value for publishers only by redistributing the value in the system". The main drivers of this change include the rise of the Internet and ICTs, the introduction of printing-on-demand, and the rapid evolution of e-book readers (Ronte, 2001). Printed books have been in existence for more than 500 years, while e-books came along just forty years ago (Chrystal, 2010). Therefore, the revolution is disruptive but slow. Throughout the printed book's history, advances were made in book materials and printing processes, but "the basic bound format remained essentially unchanged since antiquity" (OECD, 2012, p. 10). The first attempts at introducing e-books failed. Heavy, low-tech materials and high prices were major barriers to the widespread diffusion of the first e-readers (Gaymard, 2009). As a consequence, early e-reader projects, including Cybook, Gemstar ebook, and Librié, failed between 2001 and 2004 (Patino, 2008).

One effective change was the implementation of new materials in e-readers. Several companies started to develop specific reading software for different formats and various reading terminals. Printed books have never been influenced by new technologies that rendered previous book formats obsolete, but e-books are constantly evolving in terms of formats and types. This technological evolution creates challenges for both traditional printed books and e-books (OECD, 2012).

As such, the digital revolution supports disruptive economic changes in the traditional bookpublishing industry. New business models; new players, such as technological suppliers; and new distribution channels, such as aggregation platforms (Benghozi \& Salvador, 2014), are appearing on the market. From this point of view, identifying the successive technological developments is particularly interesting. The different technical steps and various devices reflect the strategic directions of designers wishing to compete with traditional paper books (eink), to position themselves in relation to tablets and other media (color and screen size), or simply to position themselves in relation to competing e-readers (autonomy). The evolution in the technological trajectories of the different versions of the six main e-readers reflects the consequences of this revolution. It encompasses a combination of repeated and disruptive innovations, as well as standardization dynamics and specialization strategies. The following analysis describes the extent to which these alternatives have contributed to movements toward convergence and/or differentiation.

\section{Methodology}

In order to clarify the successive innovative steps in the e-reader market, we used an analytical and methodical codification of the main technological characteristics of all versions of the most diffused e-readers available on the market since the start of the e-book revolution. It is difficult to find official data about the exact number of e-reader producers active on the market because the market is evolving rapidly. Dozens of e-book reader producers can be identified through a simple search on Google. However, a systematic analysis demonstrates that most of these producers are barely present on the marketplace and that they distribute on a very limited basis. In order to ensure a trustworthy methodology and reliable results, we focused on a panel of the most diffused and the most well-known devices in order to explore how their different versions evolved over time. Our panel consisted of six e-readers: Kindle, Kobo, Nook, Bookeen, Pocketbook, and Sony. ${ }^{9}$ Our methodological choice is supported by the fact that these e-readers

\footnotetext{
${ }^{9}$ See the Introduction.
} 
are among the leaders in the market based on their revenue, and their popularity and diffusion within or outside of Europe (see Appendix A and Table 1).

On the basis of a deep analysis of the different versions of these six e-readers, we investigated the specific technologies that influenced their characteristics and classified the versions into various groups. The official specifications published in the producers' catalogues were complemented with exploration of the technical documents published by the suppliers. They were also complemented with technical information collected from professional and industrial websites. This data-collection process enabled us to study the specificities of these technologies in detail. The main technology groups that we identified revealed that several specific technologies were introduced for ink and display characteristics, for light and image quality, for sound properties, and for augmented e-books (see Appendix B for details).

The methodical exploration of these six main actors in the e-book market and of the specific characteristics of their e-readers allowed us to develop an analytical map. We analyzed this map in detail by comparing the six devices on the basis of key technological variables that we identified thanks to a notable evolution in the variables. In the following, we present the results of this comparison, which clearly highlights a general convergence towards common values. In other words, convergence prevails.

\section{Analysis of results: the strategic and technical trajectories of the six "star" e-readers 10}

We analyzed e-readers ${ }^{11}$ produced by Amazon (Kindle), Barnes \& Noble (Nook), Bookeen (Cybook), Sony (PRS e-reader), Kobo, and Pocketbook. These actors are typically viewed as pioneers in this field, and they are among the best-known e-reader producers in the EU and international markets (see Appendix A and Table 1).

The first version of the Kindle, for which more than 90,000 e-books were made available (MarketLine, 2013), was originally released by Amazon in the United States in November 2007. Its successor, the Kindle 2, was introduced in February 2009, and the expanded version, Kindle DX, was brought to the market in June 2009 (Loebbecke et al., 2010). It total, five generations of the Kindle were released by Amazon between 2007 and 2013 (MarketLine, 2013). Kindle is the only mainstream e-reader on the market with a proprietary format (AZW) - Amazon has resisted embracing the e-pub format (OECD, 2012).

Barnes \& Noble, a Fortune 500 company and leading physical book retailer in the US, entered the market with its Nook in 2009. The company began developing an international strategy in 2013.

The Cybook was released by Bookeen, a French enterprise founded in 2003. The company deals with e-books and consumer electronics, and it now leads the French e-book reader market. The company's history testifies to its innovative capacities.

Sony, a leading manufacturer of electronic products for the consumer and professional markets, released the Librié ${ }^{12}$ e-reader in 2004 . The failure of this product was followed by the US launch of the Portable Reader System (PRS) in 2006. Since 2012, the PRS has also been available in the EU. Twelve versions of the PRS have been released since 2006.

In 2010, the Kobo e-reader appeared on the market. Kobo was founded in 2009 in Canada, and it was acquired by the Japanese Internet retailer Rakuten in 2011-2012. Kobo is a technological

\footnotetext{
${ }^{10}$ This section has benefited from the empirical contributions of Anissa Zineelabidine and Tridibesh Dey (Ecole polytechnique students, 2013-2014).

11 The data used here were up-to-date as of December 2013.

12 "Sony launched its first reading device, Librié 1000-EP, in Japan in April 2004, in partnership with Philips and E Ink. Librié was the first reading device to use the E Ink technology, with a 6-inch screen, a $10 \mathrm{M}$ memory, and a 500-ebook capacity" (Lebert, 2009, p. 79).
} 
manufacturer that can be viewed as a "pure player", as it specifically targets the digital book industry.

Finally, Pocketbook is a leader in e-reader production in Eastern Europe. It is a Ukrainian enterprise founded in 2007 and based in Hong Kong. In 2013, Pocketbook signed a partnership with TEA (The Ebook Alternative), the French leader in open-source software solutions for selling and reading e-books.

Table 1 offers a snapshot of the main features of these six e-reader producers.

Table 1: Main features of the six e-reader producers

\begin{tabular}{|l|l|l|c|c|c|c|c|}
\hline E-reader & Producer & Country & $\begin{array}{c}\text { Producer's } \\
\text { sector }\end{array}$ & $\begin{array}{c}\text { Year of } \\
\text { first } \\
\text { e-reader }\end{array}$ & $\begin{array}{c}\text { Year } \\
\text { entered } \\
\text { international } \\
\text { market }\end{array}$ & $\begin{array}{c}\text { Tablets } \\
\text { available } \\
\text { since }\end{array}$ & $\begin{array}{c}\text { Number of } \\
\text { versions } \\
\text { through } \\
\text { Dec. 2013 }\end{array}$ \\
\hline Kindle & Amazon & USA & $\begin{array}{c}\text { E- } \\
\text { commerce }\end{array}$ & 2007 & 2009 & 2011 & $\begin{array}{c}8 \text { e-readers } \\
5 \text { tablets }\end{array}$ \\
\hline Nook & $\begin{array}{l}\text { Barnes \& } \\
\text { Noble }\end{array}$ & USA & Book retail & 2009 & 2013 & 2012 & $\begin{array}{c}5 \text { e-readers } \\
2 \text { tablets }\end{array}$ \\
\hline Cybook & Bookeen & France & $\begin{array}{c}\text { Consumer } \\
\text { electronics }\end{array}$ & 2003 & 2003 & 2013 & $\begin{array}{c}6 \text { e-readers } \\
1 \text { tablet }\end{array}$ \\
\hline PRS & Sony & USA & $\begin{array}{c}\text { Consumer } \\
\text { electronics }\end{array}$ & 2006 & 2012 & N/A & 12 e-readers \\
\hline Kobo & Kobo & Canada & $\begin{array}{c}\text { Consumer } \\
\text { electronics }\end{array}$ & 2010 & 2010 & 2012 & $\begin{array}{c}6 \text { e-readers } \\
4 \text { tablets }\end{array}$ \\
\hline Pocketbook & Pocketbook & Ukraine & $\begin{array}{c}\text { Consumer } \\
\text { electronics }\end{array}$ & 2008 & 2009 & 2013 & 18 e-readers \\
tablets
\end{tabular}

Source: Authors' personal elaboration

In order to analyze the evolution of the technological trajectories of the various versions released by these six e-reader producers, we first identified and focused on several specific variables. As these variables show changes and improvements over the years, they reflect the technological evolution of the different versions of e-readers over time. The variables are also those on which the different e-reader producers compete and differentiate themselves. They are therefore those that support the benchmarks usually covered in marketing targeted at consumers. The variables are: weight, screen size, autonomy, Internet connectivity, and memory capacity.

All of the innovation technologies introduced by the e-reader producers were identified and investigated. Appendix B shows the specificities of these technologies. The "weight" variable was chosen as a strategic factor related to mobility and differentiation from personal computers and laptops. This variable is directly linked to "autonomy" and "Internet connectivity", while "screen size" is linked to comparisons with traditional printed books and paperback editions. Finally, "memory capacity" is a key factor for marketing strategies aimed at differentiation from physical libraries.

We also identified other variables, such as compatible formats, screen resolution, and the presence or absence of a dictionary or a USB port. This second set of variables was related to incremental innovations and did not significantly influence the market structure. Nevertheless, these variables have been used to enhance our description of the results where necessary.

Finally, we compared technological variables, such as weight and screen size, as well as the competitive positions of the e-readers in terms of their pricing strategies. Along these lines, we reconstructed the longitudinal price evolution in order to consider the decisions made by providers with regard to price.

The following sections illustrate the results of our analysis of the evolution of the technical characteristics, as well as the results of our comparisons of several other variables and the shifts in price. 


\subsection{The evolution of technical characteristics: weight, screen size, autonomy, Internet connectivity, and memory capacity ${ }^{13}$}

Weight was the first characteristic we considered. It serves as a good proxy of strategies to facilitate users' mobility, and of firms' efforts to differentiate themselves from printed books on the one hand, and computers and laptops on the other hand. Figure 1, which illustrates the evolution of e-reader weight from 2006 to 2013, shows a notable level of convergence for all six e-reader producers. From the initial, relatively heavy versions, there has been a convergence towards a weight of about 200 grams. The biggest shift in this regard is evident between 2011 and 2013. Cecere et al. (2015) examine the innovation strategies of companies in the market for smartphones. They observed a similar reduction in the degree of weight-related differentiation since 2008.

Figure 1 illustrates the evolution from diversification to convergence in the focal e-readers.

Figure 1: Weight (grams), 2006-2013

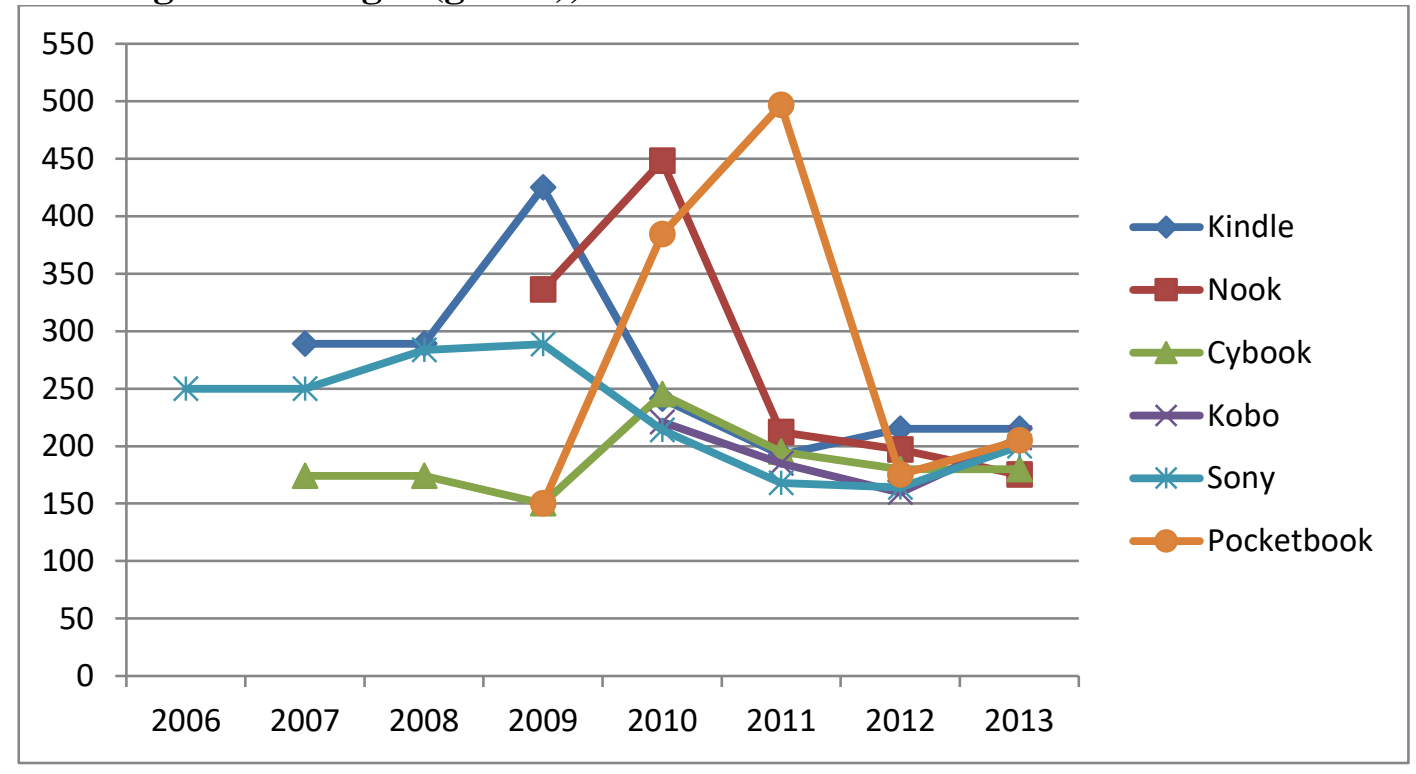

A similar trend towards convergence can be observed in the evolution of screen size, which is shown in Figure 2. As of 2013, most screens were six inches. Screen size is interesting, as it gives a good indication of the devices' positioning on the market. Manufacturers face strategic alternatives in relation to this factor. They can choose to reduce the screen size in order to compete with traditional printed paperbacks, or to enlarge it in order to follow the trends driven by laptops and tablets, and to support multimedia activity.

Figure 2: Screen size (inches), 2006-2013

\footnotetext{
${ }^{13}$ We considered only the e-reader versions (not the tablets).
} 


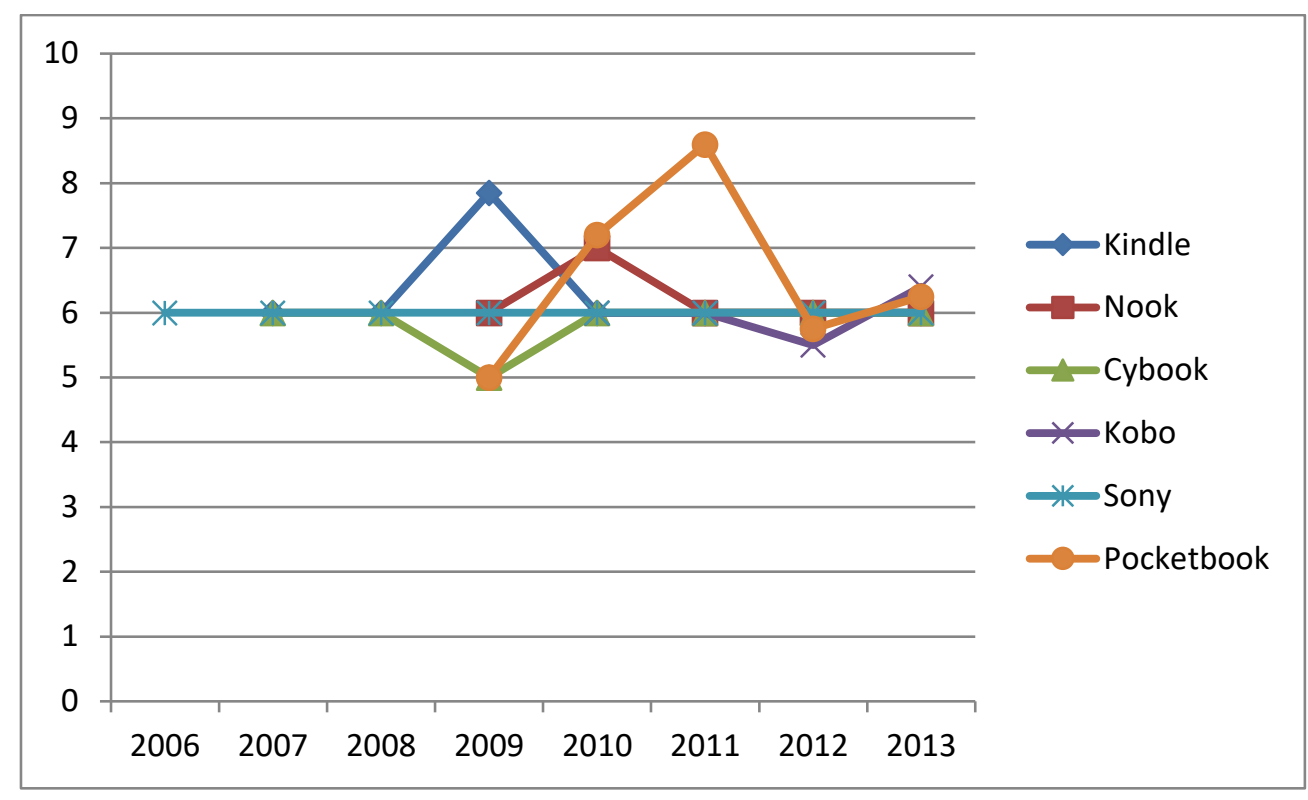

The weight-related strategy has implications for autonomy, where convergence (rather than differentiation) is again the keyword. Figure 3, which illustrates the evolution of autonomy (in terms of battery life), shows that a huge increase in autonomy has occurred over the years. From the initial convergence to thirty days of autonomy, one can observe a trend towards a capacity of sixty days starting in 2011.

Notably, Sony ${ }^{14}$ and Pocketbook ${ }^{15}$ initially tried to escape comparisons based on autonomy. These companies proposed alternative measures: the number of pages turned, hours used, and milliamperes used. However, more recent versions (2011-2013) from these producers focus on battery autonomy, just like the other e-readers. Therefore, the Sony e-reader's autonomy capacity has risen from thirty days in 2011 to sixty days in the 2012 and 2013 versions. Pocketbook has an autonomy capacity of up to one month, although it still focuses on the number of pages turned and/or hours of daily reading. In short, it seems that some specialization focused on the "way" of presenting a particular characteristic, has occurred. Nevertheless, the actual information provided is relatively similar across most of the e-readers.

An attempt at differentiation can be identified for Cybook. Figure 3 highlights Cybook's low autonomy capacity relative to the others. This is explained by the use of the Front Light technology. With Front Light technology, the light on the surface of the screen is guided through a special film that evenly diffuses light. The light is not emitted from the rear or the top, but directly illuminates the text and improves contrast. Front Light uniformly illuminates the screen, thereby making night-time or low-light reading more enjoyable. This technology provides 20 different levels of brightness. The Cybook's Front Light can be adjusted using the regulator on the touchscreen. However, the Front Light uses notable amounts of energy, which explains why the autonomy capacity is lower than among the other e-readers. This

\footnotetext{
${ }^{14}$ For the first version of Sony e-reader (2006-2008), the autonomy capacity was described as the number of "page turns" per charge (usually 6,800-7,500).

${ }^{15}$ For example, the Pocketbook Basic 611 appeared in 2012. The autonomy capacity of this products was described on the company's official website as follows: "The capacity of the built-in lithium-ion polymer battery is 1000 $m A$. Once charged, the battery will be sufficient for reading 8,000 pages. The device can work for one month without recharging, provided the built-in Wi-Fi module is off" (http://www.pocketbookint.com/au/products/pocketbook-basic-611). The autonomy capacity of the Pocketbook Pro602 (appeared on the market in 2010) was described on the website as follows: "A single battery charge provides PocketBook Pro 602 with enough power to read 20 standard books, about 14,000 page turns, or a month of two-hour daily reading" (http://www.pocketbook-int.com/us/products/pocketbook-pro-602, last accessed October 7, 2015).
} 
specialization is not without drawbacks, as producers cannot forecast whether the readers will prefer more autonomy capacity or a more advanced lighting technology.

Figure 3: Autonomy (days), 2006-2013

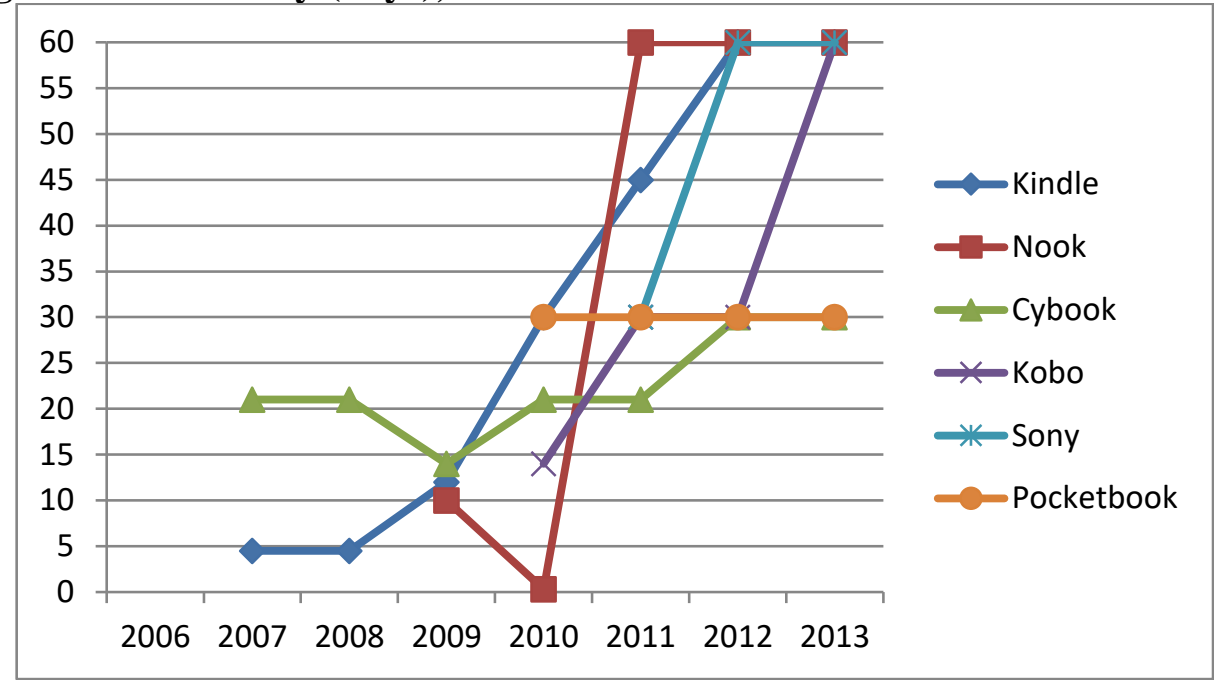

Another dimension of mobility is connectivity and, therefore, the availability of embedded ebooks and e-books available through "the cloud". Figure 4 illustrates the evolution in Internet connectivity. Wi-Fi connections are the most diffused solution. While Kobo and Cybook offer only Wi-Fi connections, Nook, Sony, and Pocketbook offer a Wi-Fi connection and a 3G connection in some models. However, these producers have also chosen to use the simplest type of Wi-Fi connections. Kindle seems to be the only e-reader that has maintained the Wi-Fi and $3 \mathrm{G}$ solution. The Kindle's built-in 3G connectivity is free and it uses the same wireless signals as mobile phones, but without monthly fees or commitments because Amazon pays for the $3 \mathrm{G}$ wireless connectivity. The $3 \mathrm{G}$ connection enables users to download books anytime, anywhere, without having to find a $\mathrm{Wi}-\mathrm{Fi}$ hotspot. The consequence is that the price is higher than for ereaders providing only a Wi-Fi connection. Therefore, this specialization choice may have drawbacks owing to uncertainties regarding consumers' price caps.

Figure 4: Internet connectivity, 2006-2013 


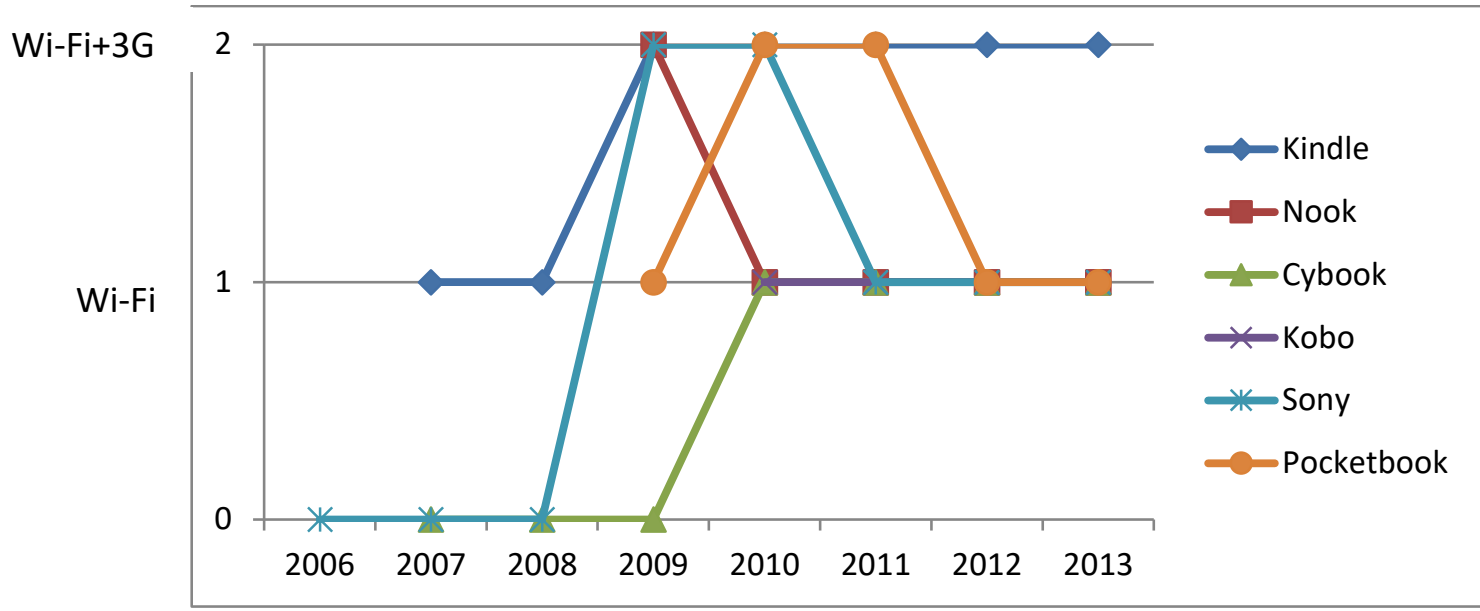

The next relevant feature is memory size. This characteristic is interesting because one important part of the marketing assertions refers to the capacity to store users' libraries. In addition, memory size provides good indications of the strategic moves of e-reader producers related to multimedia, enriched electronic books, and applications. Until 2009, the different ereaders did not exceed a capacity of 2 GB. Since then, an improvement in memory capacity towards 4 GB has been observed due to new formats arriving on the market, like image, audio, and Comic Book Rar, which required more memory. Therefore, Figure 5 shows the evolution from 2 GB towards 4 GB.

Some e-readers, like Sony and Cybook, have a standard memory capacity of 2 GB, but the internal memory space can easily be expanded with an optional microSD card that can hold tens of thousands of books. The trend to convergence is confirmed in relation to this variable as well.

Figure 5: Memory capacity (GB) evolution, 2006-2013

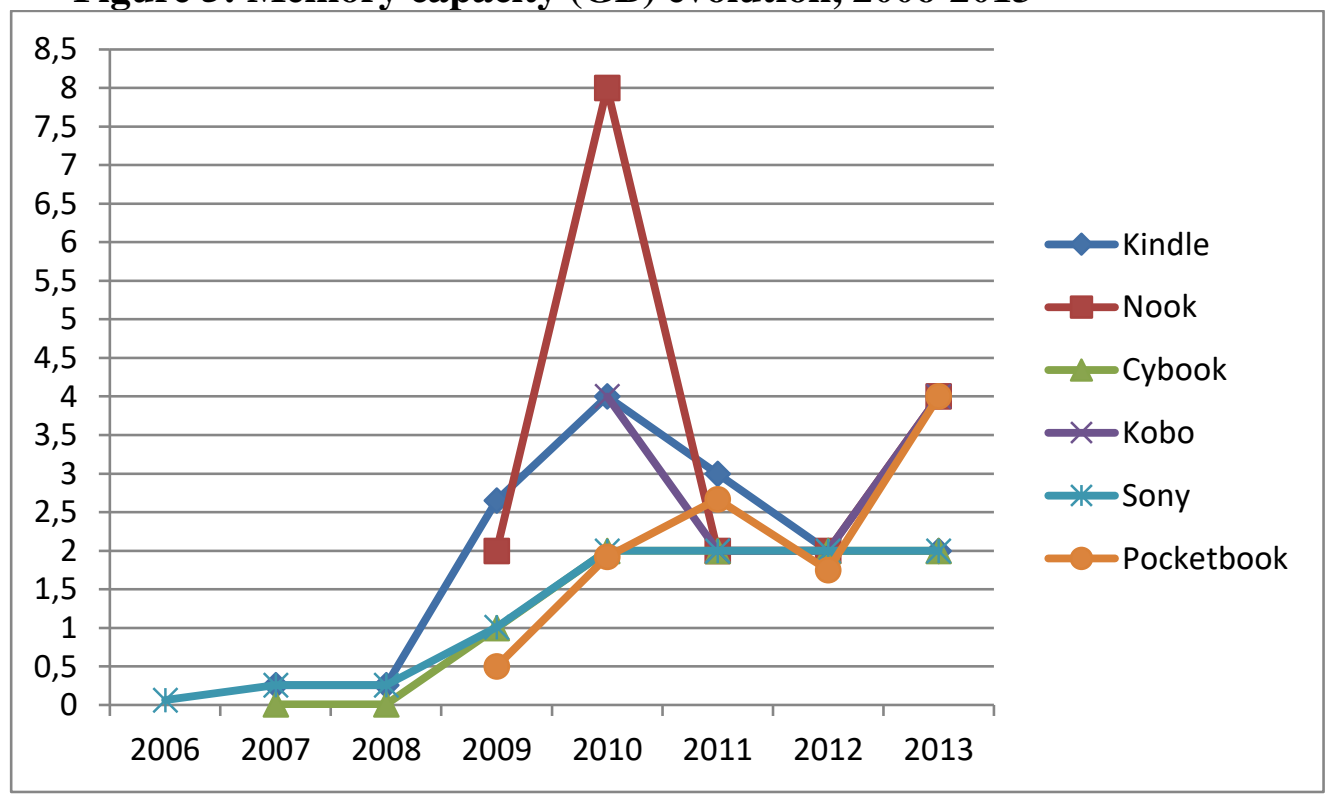

\subsection{A comparison of weight and screen size}

The technological trajectory evolution of the six e-readers described in the preceding section highlights a general preference for introducing imitative innovations and adopting a 
standardization attitude. These trends are linked to some specific secondary specialization choices.

A comparison of the evolution in weight and screen size among the different versions of these e-readers indicates a correlation between the two variables (Figure 6). The different versions of the Kindle provide a clear example, as larger size is associated with more weight. The same trend is evident for the other e-readers. This highlights a coherent and logical movement that demonstrates simultaneous parallel evolution (towards convergence) of correlated variables.

\section{Figure 6: Comparison of weight and screen size of different versions of the Kindle}

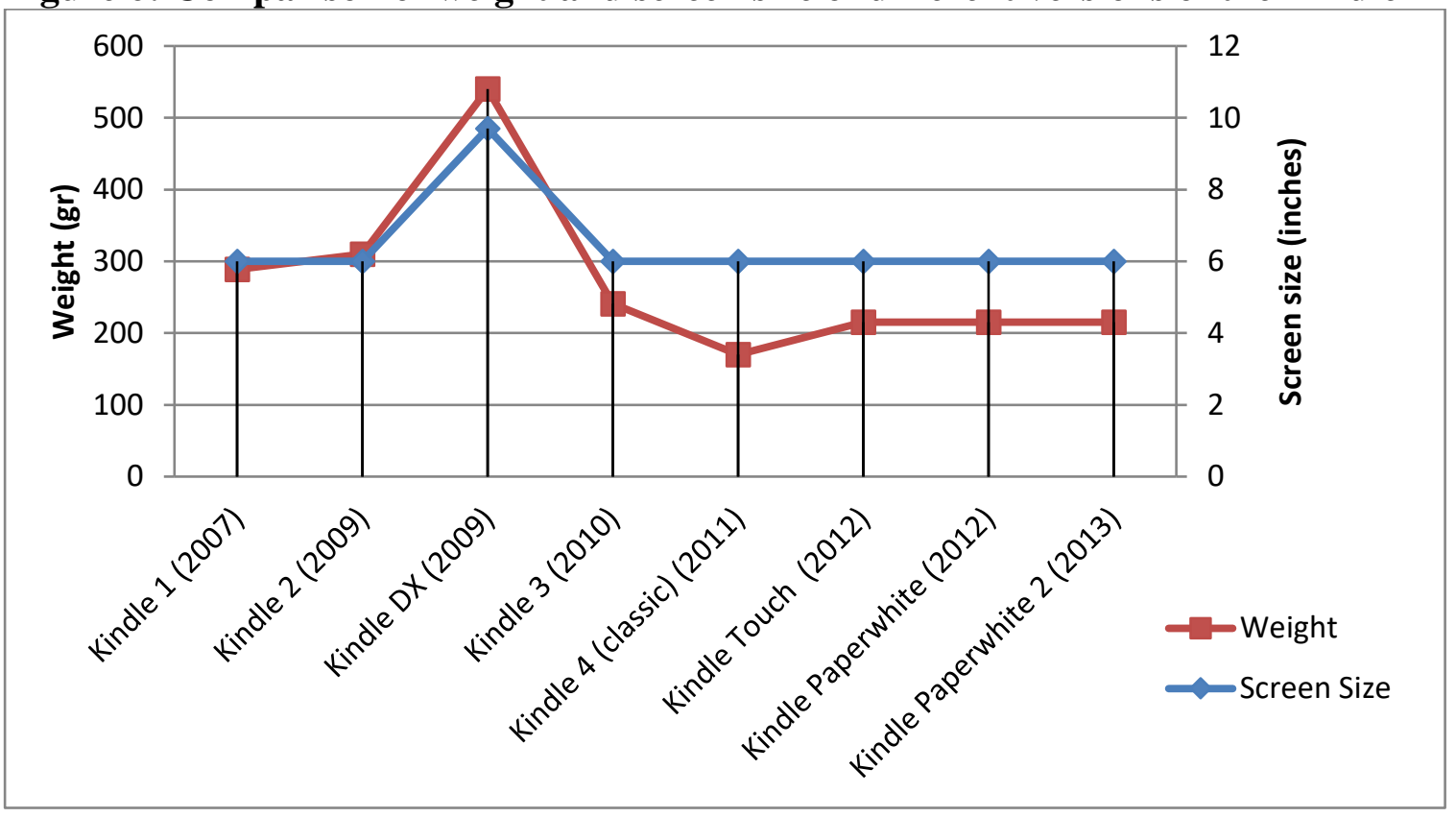

\subsection{Price evolution}

In addition to competition on quality and technology, one traditional dimension of the market and competitive positioning is price. This dimension positions e-readers relative to alternative devices (e.g., tablets, laptops, smartphones) and provides a good indication of the targeted markets (e.g., intensive consumers, news readers). Firms must decide whether to adopt a standard price or to develop a specialization strategy. In order to compare the prices of the different versions, we have used the official prices posted on the websites of each e-reader producer. As a consequence, the USD price has been used for US producers and the EUR price has been used for European producers. On a general level, we observe a progressive decline towards a standard price of USD 150-200 dollars, although the prices are never the same because subtle differences emerge.

Figure 7 highlights this general tendency, which has been evident since the introduction of the first Kindle in 2007. More specifically, while the price of the Kindle 1 was USD 399, the Kindle Paperwhite 2, which was released in 2013, was priced at USD 139. ${ }^{16}$ Notably, the latter is considered to be one of the highest-quality e-readers available on the market - it has a higher resolution and a higher-contrast touchscreen than previous editions (MarketLine, 2013) as well as built-in light technology (see Appendix B for details). Another particularity of the Kindle models is that Amazon decided to have only one model of its e-reader available at any time. It waited for a new model before withdrawing the previous model from the market. Kindle

\footnotetext{
${ }^{16}$ The Kindle is somewhat unusual in that prices differ depending on whether the user agrees to be exposed to advertising (in which case, the price is about USD 30 lower). However, as the other e-reader producers do not offer this possibility, we have decided to only use the price for Kindles without advertising.
} 
provides a classical illustration of the life curve of technical products in which the price drops quickly over time but the producer (i.e., Amazon) strives to regularly rebuild some value through innovations and the introduction of new products at cheaper prices.

In May 2010, the Kobo e-reader was released. It was one of the cheapest e-readers on the market with a price of USD 149. Amazon dropped the price of its Kindle in response to the Kobo competition (MarketLine, 2013).

Figure 7: Price evolution of Kindle e-readers and the Kindle Fire tablet

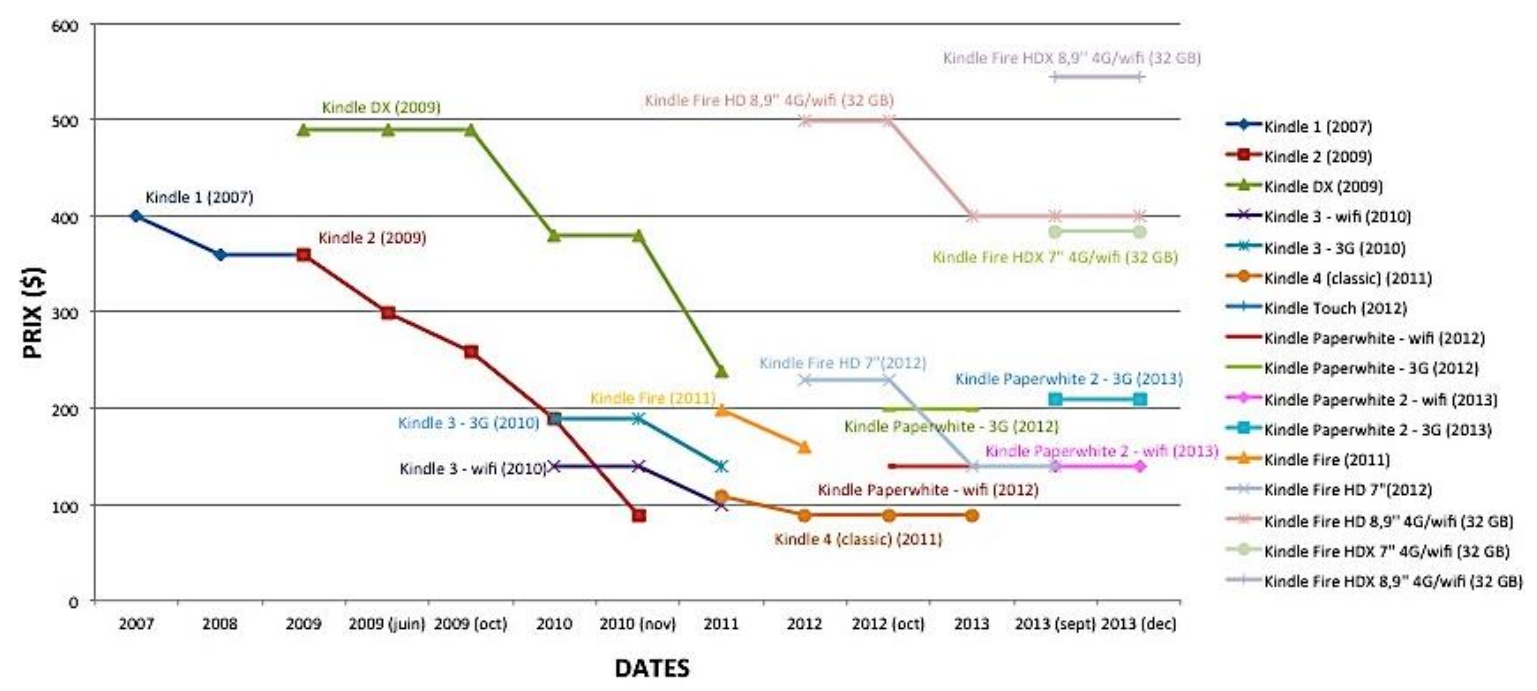

With regard to pricing strategies, a comparison of the dominant leader Kindle with its competitors is interesting. Figure 8 features the price evolution of the Nook. Barnes \& Noble, the Nook's producer, adopted a pricing strategy based on technological innovations in order to regularly enrich the quality of its products while taking advantage of the gains in productivity enabled by the innovations. Despite this strategy, Figure 8 shows that the evolution of the Nook's price is similar to that of the Kindle. The first model, the Nook Classic 3G, was introduced in 2009 at a price of USD 259. The most recent model, the Nook Glowlight, was sold in 2013 for USD 119 dollars. Notably, the latter offers more functionality.

These two cases illustrate the general trend observed for all e-readers. Prices fall across the board over time. Moreover, this decline is not offset by the technological advances that might allow for higher prices. 
Notwithstanding the clear and progressive decline in prices shown in Figures 7 and 8, a differentiation strategy focused on high-range products and technological innovation is evident. This strategy might be aimed at keeping prices flat rather than at supporting competition. In these cases, one may observe specialization associated with improved functionality.

Figure 8: Price evolution of Nook e-readers and the Nook HD tablet

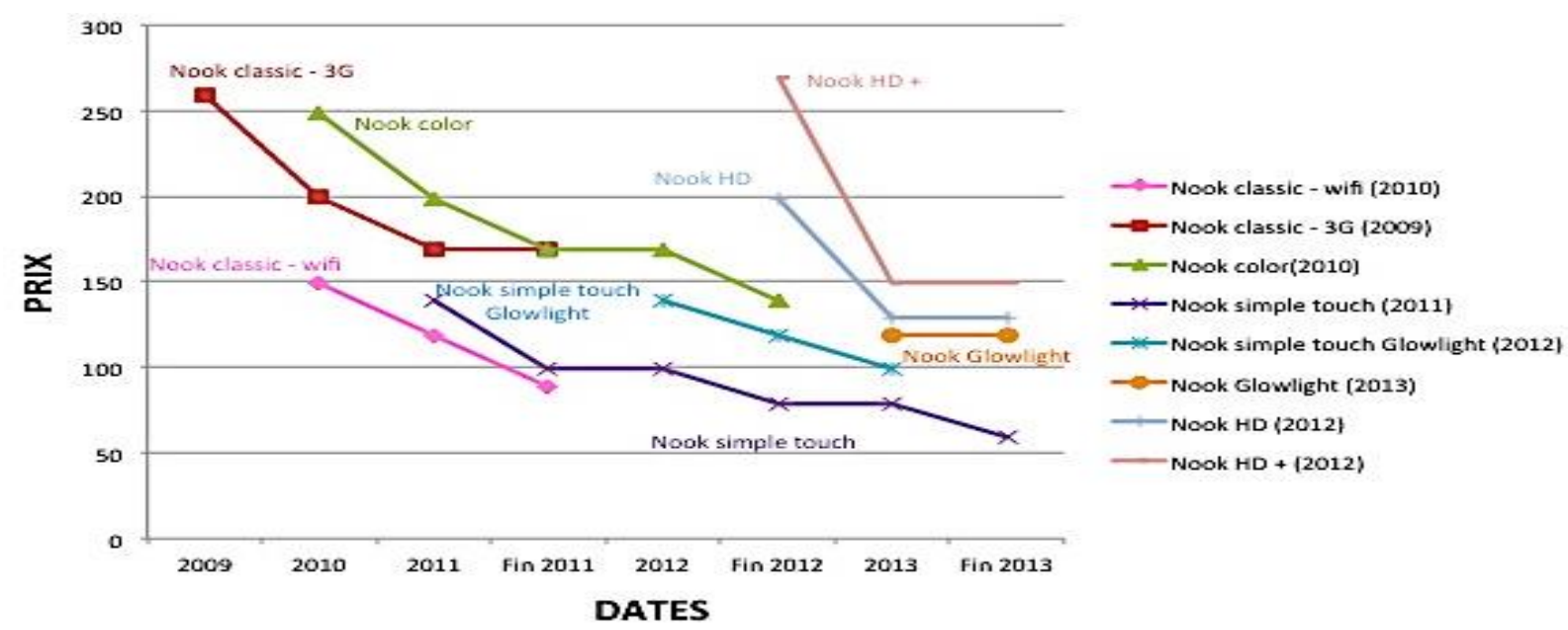

\section{Discussion}

In contrast to the music and cinema sectors, the book-publishing sector experienced a relatively late and less severe impact from the digital revolution. However, the Internet and ICTs have radically affected the book-publishing industry, which has traditionally been a low-growth business (OECD, 2012). According to the European Commission (2005, p. 71), "parts of the [book publishing] industry have focused on cost reduction rather than on product innovations that might grow the overall size of the market... As a consequence, technological innovation turns to be limited; a large number of new products are created that are very similar to previous products. Major product innovations happen more rarely and this has conditioned the culture of the publishing industry". By mapping the phases of the R\&D value chain in the e-book publishing sector, we have been able to highlight the key role of technology (Benghozi \& Salvador, 2015).

In this context, the objective of this paper has been to investigate how successive technological innovations and pricing strategies contribute, over the long term, to shaping the market design and the structure of the offering. In addition, we have aimed to uncover how these technological trajectories foster movements toward convergence or differentiation, which relate to standardization and specialization, respectively. By comparing the technical trajectories of all of the e-readers, we are better able to understand the components in which economic actors invest and those on which they differ, as well as the different rhythms of evolution and the aggregate dynamics.

Our analysis is not without limitations. First, we analyzed six e-reader producers. These producers do not represent the entire e-reader universe, but they are among the main and most 
diffused actors in the market. Second, we focused on some key variables. Our analysis does not cover all of the technical characteristics identifiable in an e-reader, but it pays attention to the most important variables linked to technological evolution and useful for comparisons among different producers. Third, all of the e-reader producers analyzed here have an international strategy. In future research, it would be interesting to investigate whether different strategies and specificities are identifiable in the various countries, or at the EU or EU-external level.

Despite these limitations, the results of our analysis are interesting in several ways. First, we observed a process of technological rivalry involving a repeated innovation strategy, as well as coopetition and coevolution. Second, we discovered that the imitation processes adopted by the e-reader producers enabled them to introduce innovative advancements for reciprocal advantage.

Given Amazon's e-reader strategy and the fact that Amazon has been the most effective pioneer among e-reader producers, we argue that a path-dependent process (David, 1985) is linked to the logical incrementalism phenomenon. In other words, the repeated innovations adopted by the e-reader producers in their coopetitive, coevolutive, and imitative approach reveal a context in which no leader can be identified. Instead, a step-by-step emergence of an ecosystem of companies is observable. In this ecosystem, constant technological improvements are strictly linked to the aim of catching and retaining as many consumers as possible. The similarities observable among the various e-readers imply that buying one e-reader or another is basically the same thing. The difference lies in consumers' use of their e-readers. This explains the convergence in the variables (i.e., weight, screen size, autonomy, Internet connectivity, and memory capacity) and the focus on minor but continual technological improvements. In the digital era, consumers are mainly captured and retained through technological advancements. The price evolution reflects this obsessive focus on technology. In contrast to traditional industries, technological improvements in this field are not necessarily associated with an increase in prices. Paradoxically, it seems that consumers decide the price of a device because the aim of the final price is to capture consumers. This consumer involvement is not drastically different from the involvement of consumers in a firm's process of idea generation and product development through Internet platforms, as highlighted by Tran (2014) in a recent study focused on collaborative technologies. Similarly, Goolsbee and Syverson (2008) find that incumbents in the airline industry significantly cut average fares when a route is threatened by potential entrants. The lower prices appear to increase the number of passengers flying with the incumbent on the directly threatened route. Similarly, our analysis reveals that when an e-reader producer decreases the price of its product, its competitors make the same move. One might wonder whether this strategy is sustainable because consumers now require steady innovation on a regular basis.

On this basis, we can deduce that, as in the overall high-tech mobile sector, competition in the e-reader market is based more on new functionalities than on prices. An example from the music sector confirms this trend. Larribeau and Pénard (2003) find that the dispersion of album prices is a persistent phenomenon on the digital market, and that it fosters intense competition and alternative strategies among cyber-merchants. However, this also enables a shift from very competitive situations to more relaxed competitive contexts or even to collusion. Finally, the authors point out that the intensity of the consumers' requests is a key aspect for price policies. In fact, the technological trajectories followed by the e-reader producers suggest that successive generations aim to temporarily preserve any existing price premiums. Consequently, innovation strategies - specialization or standardization - become increasingly important. As actors cannot differentiate themselves on the basis of price, they are forced to choose a differentiation strategy focused on technological improvements. They are therefore caught in a paradox: they are obliged to invest in technological advancements in order to differentiate themselves from competitors, but those technologies are inclined to move towards standardization. Therefore, 
producers cannot really differentiate themselves in terms of either technologies or prices. The ultimate effect of this paradoxical situation is that it becomes important to be among "the first movers" on the market in order to gain at least a temporary monopoly.

The emergence of platforms clearly reflects this context. Platform leaders successfully build products, services, or technologies that then become the shared technological basis on which other companies develop their offers. The underlying architecture is basically the same: standardized components coupled with a set of differentiated peripheral components that provide additional value. Platform leaders also create network effects and new forms of domination, such as the control of proprietary standards and patents, which provide support for new forms of innovation. The leader position cannot be attributed to a given firm on a specific market, but instead to the competitive advantage that gives a firm a leading position in the architecture of platforms active in several markets.

The way in which technological trajectories are built is illustrated by emerging phenomena resulting from the reciprocal observation and sharing of the same technological patterns. Pfeffer and Salancik (1978, p. 1) and Aldrich and Ruef (2006, p. 159) stress the "importance of context" for understanding organizational behavior. According to Aldrich and Pfeffer (1976, p. 99), from the perspective of the evolutionary model, one could argue that "the environment must have changed to give a selective advantage to particular forms at a given time". Therefore, the effectiveness of organizations rests on their ability to acquire and maintain a set of resources, and to transact with other elements in their environment to acquire them. In the frequent and radical changes taking place in the digital age, the e-reader producers face the prospect of either not surviving or changing their activities in response to these environmental factors. From this perspective, the technological and pricing dynamics can be interpreted in terms of coopetition (Brandenburger \& Nalebuff, 1996; Ritala, 2012; Bouncken \& Fredrich, 2012; Ritala \& Hurmelinna-Laukkanen, 2013; Ritala \& Sainio, 2014). When e-reader producers adopt an imitative-coopetitive strategy, the economic actors aim to consolidate the global market while maintaining their market shares. At the same time, they attempt to gain some minor productivity advantages.

Is it possible to affirm that this is coopetition in the strict sense? The nature of the technological decisions related to the focal variables leads us to argue that this is actually a phenomenon of parallel development that starts from the same technical basis. In other words, rather than coopetition, we may observe some competitors collaborating strategically and in parallel with the same third-party supplier and adopting a type of "logical incrementalism" in strategy formulation (Quinn, 1978). According to this logic, strategic decisions do not come into existence through aggregation in a single and simultaneous decision matrix. As Quinn (1978, p. 17) states, "it is virtually impossible for the manager to orchestrate all internal decisions, external environmental events, behavioural and power relationships, technical and informational needs, and actions of intelligent opponents so that they come together at any precise moment". The logic involves subsystems of strategy formulation based on minor decisions made logically, incrementally, and consciously on the basis of experimentation and learning. These decisions are also made according to the context and the subset of people involved.

Significant differences can be observed in a comparison of the e-reader market's technological characteristics and the e-book industry. The e-book industry responded to retail chains' challenges with product and marketing innovation (e.g., print-on-demand) as well as increased efficiency, but it has not responded with significant technological innovations, or with complete restructuring of publishing houses and channels. In contrast, the e-reader market has undertaken constant and significant technological innovation. Amazon is one of the most notable examples of such strategic moves, which have been successfully supported by technological platforms (e.g., supply chain and e-bookstore), business models (e.g., B2B web services), and specific 
devices (i.e., the Kindle). Each of these moves contributed to building and enriching a leading, global ecosystem focused on nurturing a positive relationship with consumers. Consumers buy the Kindle from Amazon.com, buy e-books from Amazon through their Kindles or computers, and read those books on the Kindle. As a consequence, Amazon "has had one of the fastest growths in the Internet's history, even as compared to eBay and Google. Amazon has since become an e-commerce platform for others, thanks to its pioneering retail e-commerceleshopping business in many product categories, not just books" (Simon \& de Prato, 2012, p. 13). Amazon's strategy is said to be to sell Kindles at cost because it wants to make money when people use the devices, rather than when they buy them (MarketLine, 2013). ${ }^{17}$

Another key factor appeared in the e-reader ecosystem when Amazon.com and Apple launched a coopetition strategy after the release of the iPad in April 2010 (Ritala et al., 2014). The iPad is both an e-reader and a tablet, and it includes the iBooks application. However, Apple started to distribute Amazon.com's e-books through the Kindle application. According to Ritala et al. (2014, p. 242), "Amazon.com has pursued coopetitive benefits in making the Kindle app available on Apple's iPad. This application allows iPad owners to read e-books in Amazon.com's proprietary e-book format AZW, while Amazon.com's Kindle e-reading devices (including the recent Kindle Fire) compete with Apple's iPad". Following the success of the iPad, various manufacturers have released multi-function tablets. Consequently, they established a new standard for computers, devices, and services, and they therefore compete with dedicated e-readers (Miller, 2013). By developing a new technological trajectory that intersects with e-readers, the tablets contribute to enhancing the technological rivalry in this sector. They are now also drawing an alternative path based on repeated innovation (e.g., phablets, hybrid laptops, 4G connectivity).

\section{Concluding remarks}

The technological movements observable in the e-reader market are evidence of the actual digital-technologies world. The technologies are often easily re-combinable, they are strongly evolutive, and they mix infrastructure effects and software innovation.

The case of emerging platforms is indicative of this trend. The technological trajectories of the platforms are built on the tensions between two conflicting objectives: specializing in making the most from proprietary systems or obtaining the broadest customer base by adopting openness, interoperability, and standardization. In the former case, competition takes place and strengthens between exclusive ecosystems controlled by the repetition of innovations. In the latter case, market consolidation is based on the expansion of innovation opportunities through open interfaces (Benghozi, 2014).

These findings are not specific to the content industries. We find similar instances in other fields directly related to information technologies, such as the market for enterprise search solutions. This area is highly structured given the articulation of several technical components (e.g., infrastructure, dedicated applications, information architecture, user interfaces) in several fields. Chamaret (2011) demonstrates that this field's competitive dynamics result from policies of innovation promoting either standardization or specialization. This author observes a shift from the economics of standardization to the economics of creativity aimed at developing competitive advantage.

Thus, standardization does not limit innovation. Instead, it fosters the promotion of incremental technological developments that support specialization strategies and repeated innovation. Standards promote trust, especially in innovative products, because they set the general minimum requirements. As stated by Swann (2010, p. 9) "standardization does constrain

\footnotetext{
${ }^{17}$ To some extent, this can be portrayed as the exact opposite of Apple's strategy of building large application stores aimed at selling attractive content to iPhone and iPad users at high prices.
} 
activities but in doing so creates an infrastructure to help trade and subsequent innovation. Standardization helps to achieve credibility, focus and critical mass in markets for new technologies". More specifically, standardization reduces the time-to-market of inventions and innovative technologies. Consequently, it promotes technological competition. As highlighted by Blind (2009), compatibility standards serve as the basis for innovation in network industries, as standards not only facilitate the substitution of old technologies with new ones, but they also enable the coexistence of alternative technical solutions.

In the specific case of e-readers, one step forward was evident in the shift from standardization to creativity identifiable in the attention paid to software, ergonomics, and design (Benghozi \& Salvador, 2015). This seems to be the main result of the competition focused on constantly introducing (minor) new functionalities. The quality of the user interface and, therefore, the creativity in design and ergonomics are intended to be the key variables as the e-readers compete with the tablets industry. Following the success of the iPhone design, Cecere et al. (2015, p. 163) analyzed whether a dominant design emerged in the smartphones market. The existence of different versions of smartphones "contrasts with the conventional wisdom concerning the emergence of a dominant industry design, which predicts that imitators tend to follow innovators and, if an innovation is commercially successful and widely adopted, it will become the dominant design because all products in the market will use that specific technology and design features". In the near future, it would be interesting to investigate whether a dominant design exists in the e-readers and tablets market. It might also be interesting to compare the technological paths of e-readers and tablets in the coming years in order to understand the extent to which the mimetic coopetitive strategies we observed among e-readers also exist between e-readers and tablets. Any resemblance in such aspects as size, screen, or connectivity might suggest that similarities are supported by technological suppliers (e.g., chip, battery, and screen manufacturers), which could lead to greater convergence of both types of devices.

\section{References}

Aldrich H. E., Pfeffer J. (1976), “Environments of Organizations”, Annual Review of Sociology, vol. 2, pp. 79105.

Aldrich, H.E., and Ruef, M. (2006), Organizations Evolving, Sage, London.

Baden-Fuller C., Haefliger S. (2013), "Business Models and Technological Innovation”, Long Range Planning, vol. 46, pp. 419-426.

Benghozi P.-J. (1990) "Managing Innovation: from ad hoc to Routine in French Telecom", Organization Studies, $\mathrm{N}^{\circ} 11 / 4$, pp. 531-554.

Benghozi P.-J. (2014), "Plateformes : quels enjeux pour la régulation?”, Les Cahiers de l'Arcep, October, pp. 5657.

Benghozi P.-J., Salvador E. (2014) "Strategies and business models of online platforms in CCIs: convergence or differentiation in the e-book sector?", in Schramme A., Kooyman R. (Ed.), Hagoort G. (2014), "Beyond Frames. Dynamics between the creative industries, knowledge institutions and the urban context", Eburon Academic Press, Delft, ISBN 9789059728844, pp. 96-104.

Benghozi P.-J., Salvador E. (2015), "How and Where the R\&D Takes Place in Creative Industries? Digital Investment Strategies of the Book Publishing Sector", article presented at the XXIVe Conférence Internationale de Management Stratégique, AIMS, 3-5 June, Paris.

Benghozi, P.J., Paris T. (2007) "The economics and business models of prescription in the Internet" in Brousseau E. and N. Curien N. [eds.] Internet and Digital Economics - Principles, Methods and Applications, Cambridge (Mass), Cambridge University Press, pp. 291-310.

Bengtsson M., Kock S. (2014), "Coopetition-Quo vadis? Past accomplishments and future challenges", Industrial Marketing Management, vol. 43, pp. 180-188.

Benhamou F. (2014), Le Livre à l'heure numérique. Papier, écrans, vers un nouveau vagabondage, Paris, Seuil. 
Blanc A., Huault I. (2014), "Against the digital revolution? Institutional maintenance and artefacts within the French recorded music industry”, Technological Forecasting \& Social Change, vol. 83, pp. 10-23.

Blind K. (2009), "Standardisation: A Catalyst for Innovation", Inaugural Address, Rotterdam School of Management, Erasmus Universiteit Rotterdam (August).

Bouncken R. B., Fredrich V. (2012), “Coopetition: performance implications and management antecedents", International Journal of Innovation Management, vol. 16, n. 5, pp. 1-28.

Brandenburger A. M., Nalebuff B. J. (1996), “Co-opetition”, Currency Doubleday, New York.

Brown, S.L., Eisenhardt, K.M. (1998), Competing on the Edge: Strategy as Structured Chaos, Boston, MA: Harvard Business School Press.

Carr, N. G. (2004), "Does IT matter? Information Technology and the Corrosion of Competitive Advantage", Boston, MA: Harvard Business Press.

Cecere G., Corrocher N., Battaglia R. D. (2015), "Innovation and competition in the smartphone industry: is there a dominant design?”, Telecommunications Policy, vol. 39, pp. 162-175.

Chalant I., Lecloux V. (2010), “L'innovation technologique en reseau: les defis de la coopetition”, Faculté de Psychologie et des Sciences de l'Education, Psychologie Sociale des Groupes et des Organisations JeanFrançois Leroy, Université de Liège, 20p.

Chamaret C. (2011), "Comment échapper à la commoditisation", Gérer et Comprendre, vol. 104, n. 2. pp. 102104.

Chamaret C. (2012), "Rôles et stratégies des firmes face à la commoditisation. Le cas des moteurs de recherche en entreprise", Thesis presented on the $2^{\text {nd }}$ of March 2012 for the degree of Doctor of Ecole polytechnique, economy and social sciences sector. Specialty: management, pages 1-355.

Chandra Y., Yang S.-J. S. (2012), « Managing disruptive innovation. Entrepreneurial strategies and tournaments for corporate longevity », Journal of General Management, vol. 37, n. 2, pp. 23-50.

Christensen C. (1997), The innovator's dilemma, Boston MA, USA, Harvard Business School Press.

Christensen C., Raynor E. M. (2003), The innovator's solution: creating and sustaining successful growth, Harvard Business Press, Cambridge, MA.

Chrystal, R. (2010) 'The Evolution of e-Books: Technology and Related Issues', Digital Libraries, INFO, pp. 147.

Corsi S., Di Minin A. (2014), "Disruptive innovation...in reverse: adding a geographical dimension to disruptive innovation theory", Creativity and Innovation Management, vol. 23, n. 1, pp. 76-90.

Dacos M., Mounier P. (2010), “L'Édition électronique”, collection Repères, Paris, La Découverte, ISBN: 9782 707157294.

Dahl J. (2014), "Conceptualizing coopetition as a process: an outline of change in cooperative and competitive interactions", Industrial Marketing Management, vol. 43, pp. 272-279.

David P. A. (1985), "Clio and the Economics of QWERTY”, The American Economic Review, vol. 75, n. 2, pp. 332-337.

Deltour F., Lethiais V. (2014), « L'innovation en PME et son accompagnement par les TIC : quels effets sur la performance ? », Systèmes d'Information et Management, vol. 19, n. 2, pp. 1-25.

Dumoulin R., Simon E. (2005), "Stratégie de rupture et PME: la replication impossible », Revue Française de Gestion, 2005/2, n. 155, pp. 75-95.

Eisenhardt, K. M. (1989), «Building theories from case study research », Academy of Management Review, vol. 14 , pp. 532-550.

Eisenhardt, K. M., Graebner, M. E. (2007), “Theory building from cases: opportunities and challenges”, Academy of Management Review, vol. 50, n. 1, pp. 25-32.

European Commission (2005) 'Publishing Market Watch: final report'.

Fitzgerald B. (2006), “The transformation of Open Source Software”, MIS Quarterly, vol. 30, n. 3, pp. 587-598.

Gawer, A. (2009), Ed., Platforms, Markets and Innovation, Cheltenham, Edward Elgar.

Gawer, A., Cusumano, M. A. (2002), Platform Leadership: How Intel, Microsoft and Cisco Drive Industry Innovation, Boston, Massachusetts, Harvard Business School Press.

Gaymard, H. (2009), "Situation du livre. Évaluation de la loi relative au prix du livre et questions prospective", Rapport à la Ministre de la Culture et de la Communication. 
Gnyawali D. R., Park B.-J. (2011), "Co-opetition between giants: Collaboration with competitors for technological innovation", Research Policy, vol. 40, n. 5, pp. 650-663.

Goolsbee A., Syverson C. (2008), "How do incumbents respond to the threat of entry? Evidence from the major airlines", The Quarterly Journal of Economics, November, pp. 1611-1633.

Greco A. (2005), The book publishing industry, second edition, Mahwah, New Jersey, Lawrence Erlbaum Associates Publishers.

Greco A. (2011), The book publishing industry, Taylor\&Francis.

Habtay S. R. (2012), “A firm-level analysis on the relative difference between technology-driven and marketdriven disruptive business model innovations", Creativity and Innovation Management, vol. 21, n. 3, pp. 290303.

Hamel G., Doz Y. L., Prahalad C. K. (1989), “Collaborate with your competitors and win”, Harvard Business Review, January-February, pp. 133-139.

Hamel, G. (1998), "The challenge today: Changing the rules of the game”, Business Strategy Review, vol. 9, n. 2 , pp. 19-26.

Hammer M. (2004), "Deep change. How operational innovation can transform your company”, Harvard Business Review, April, pp. 84-93.

Hannan, M.T. (2005), 'Ecologies of organizations: diversity and identity', Journal of Economic Perspectives, Vol 19, No 1, pp 51-70.

Hannan, M.T., Baron, J.N., Hsu, G., and Kocak, O. (2006), 'Organizational identities and the hazard of change', Industrial and Corporate Change, Vol 15, No 5, pp 755-784.

Hatchuel, A., Le Masson, P. (2006), "Growth of the firm by repeated innovation: towards a new microeconomics based on design functions", paper presented at the 11th International Schumpeterian Society, Nice-SophiaAntipolis, 21st-24th June, France, 18p.

Hatchuel, A., Le Masson, P., Weil B. (2001), "From R\&D to R-I-D: design strategies and the management of "innovation fields"”, 8 th International Product Development Management conference, Enschede, June, 16p.

Howard N. (2009), “The Book: The Life Story of a Technology”, The Johns Hopkins University Press, Baltimore, MD, ISBN 978-0-8018-9311-7.

Hsieh, C. C., Chen, J. W., Luo, D., Lu, C. C. and Huang, Y. L. (2011) 'Insights from the Technology System Method for the Development Architecture of e-Textbooks', In ICDS 2011, The Fifth International Conference on Digital Society, pp. 205-209.

Katz, M. L, Shapiro, C. (1986), "Technology Adoption in the Presence of Network Externalities", Journal of Political Economy, University of Chicago Press, vol. 94(4), pp. 822-841.

Klenner P., Husig S., Dowling M. (2013), "Ex-ante evaluation of disruptive susceptibility in established value networks - When are markets ready for disruptive innovations?”, Research Policy, vol. 42, pp. 914-927.

Larribeau S., Pénard T. (2003), “Que peut-on dire des stratégies tarifaires sur Internet ? Une étude économétrique sur la vente en ligne de CD en France », Systèmes d'Information et Management, vol. 8, n. 3, pp. $29-54$.

Le Roy F., Sanou F. H. (2014), «Stratégie de coopétition et performance de marché : une étude empirique », Management International, vol. 18, n. 2, pp. 124-139.

Lebert, M. (2009), “A short history of ebooks", NEF, University of Toronto.

Lessig L. (2006), Code and the other laws of cyberspace, Version 2.0, New York, Basic Books.

Lewin, A. Y., Volberda, H. W. (1999), "Proglomena on Coevolution: A Framework for Research on Strategy and New Organizational Forms", Organization Science, Vol. 10, No 5. Sept.-Oct. pp. 519-534.

Loebbecke, C., Soehnel, A., Weniger, S. and Weiss, T. (2010) 'Innovating for the Mobile End-User Market: Amazon's Kindle 2 Strategy as Emerging Business Model', In Mobile Business and 2010 Ninth Global Mobility Roundtable (ICMB-GMR) International Conference, pp. 51-57.

Lyubareva I., Benghozi P.-J., Fidele T. (2013), Online Business Models in Creative Industries: Diversity and Structure, Journal of International Studies in Management and Organization, forthcoming.

MarketLine (2013), Amazon's Kindle: dominating the e-book market while selling at cost price, MarketLine casestudy, January, pp. 1-20.

Markides C. (1998), "Strategic innovation in established companies", Sloan Management Review, vol. 39, n. 3, pp. 31-42.

McGahan A. M. (2004), "How industries change”, Harvard Business Review, vol. 82, n. 10, pp. 86-94. 
Miller C. (2013), "Digital-media transformation: what the e-book industry can teach us about selling digital content", Informa, Telecoms\&Media, pp. 6-12.

Murmann, J. P. (2003), The Coevolution of Industries and Academic Institutions: Theory and Evidence, Unpublished.

OECD (2012) 'E-books: Developments and Policy Considerations', OECD Digital Economy Papers No. 208.

Park, A., Lee, K. J. and Casalegno, F. (2010) 'The three dimensions of book evolution in ubiquitous computing age: Digitalization, augmentation, and hypermediation', In Sensor Networks, Ubiquitous, and Trustworthy Computing (SUTC), 2010 IEEE International Conference, pp. 374-378.

Patino, B. (2008) 'Rapport sur le livre numérique', Ministère de la culture et de la communication.

Pfeffer J., Salancik G. R. (1978), "The external control of organizations. A resource dependence perspective", New York, Harper\&Row.

Piccoli G., Lui T.-W. (2014), “The competitive impact of information technology: can commodity IT contribute to competitive performance", European Journal of Information Systems, vol. 23, n. 6, pp. 616-628.

Quinn J. B. (1978), “Strategic change: “logical incrementalism”, Sloan Management Review, vol. 20, n. 1, pp. 721.

Ragin C. C., Amoroso L. M. (2011), Constructing Social Research, The Unity and Diversity of Method, Second Edition, Sage publications.

Raza-Ullah T., Bengtsson M., Kock S. (2014), “The coopetition paradox and tension in coopetition at multiple levels”, Industrial Marketing Management, vol. 43, pp. 189-198.

Reimann, M., Schilke O., Thomas J. S. (2010), “Toward an understanding of industry commoditization: Its nature and role in evolving marketing competition", International Journal of Research in Marketing, 27(2) p.188197.

Riot E. (2013), “L'édition française à l'heure de la rupture du livre numérique”, Entreprendre \&Innover, $2013 / 2$ n. 18 , pp. 31-40.

Ritala P. (2012), «Coopetition strategy-when is it successful? Empirical evidence on innovation and market performance", British Journal of Management, vol. 23, pp. 307-324.

Ritala P., Golnam A., Wegmann A. (2014), "Coopetition-based business models: the case of Amazon.com", Industrial Marketing Management, vol. 43, pp. 236-249.

Ritala P., Hurmelinna-Laukkanen P. (2009), "What's in it for me? Creating and appropriating value in innovationrelated coopetition", Technovation, vol. 29, issue 12, December, pp. 819-828.

Ritala P., Hurmelinna-Laukkanen P. (2013), "Incremental and radical innovation in coopetition-the role of absorptive capacity and appropriability”, Journal of Product Innovation Management, vol. 30, n. 1, pp. 154169.

Ritala P., Sainio L.-M. (2014), “Coopetition for radical innovation: technology, market and business-model perspectives”, Technology Analysis \& Strategic Management, vol. 26, n. 2, pp. 155-169.

Rochet J.-C., Tirole J. (2003), "Platform Competition in Two-Sided Markets", Journal of the European Economic Association, MIT Press, vol. 1(4), pp. 990-1029.

Ronte, H. (2001) 'The impact of technology on publishing', Publishing research quarterly, 16(4), pp. 11-22.

Rouet F. (2007), “Le livre: mutations d'une industrie culturelle”, La documentation Française, Paris.

Ruling C.-C., Duymedjian R. (2014), "Digital bricolage: Resources and coordination in the production of digital visual effects", Technological Forecasting \& Social Change, vol. 83, pp. 98-110.

Sanchez R., Mahoney J. T. (1996), "Modularity, flexibility, and knowledge management in product and organization design”, Strategic Management Journal, vol. 17, Winter Special Issue, pp. 63-76.

Schlegelmilch B.B., Diamantopoulos A., Kreutz P. (2003), "Strategic Innovation: The Construct, its Drivers and its Strategic Outcomes”, Journal of Strategic Marketing, Vol. 11, n. 2, p. 117-132.

Schreyögg M., Kliesch-Eberl G. (2007), "How Dynamic can Organizational Capabilities be? Towards a dual Process Model of Capability Dynamisation”, Strategic Management Journal, vol. 28, pp. 913-933.

Siggelkow, N. (2007), "Persuasion with case studies", Academy of Management Journal, vol. 50, pp. 20-24.

Simon J. P. (2014), «Ce que le numérique a déjà changé à l'edition», INA Global, November, http://www.inaglobal.fr/edition/article/ce-que-le-numerique-deja-change-ledition-7977

Simon, J. P. and de Prato, G. (2012) Statistical, Ecosystems and Competitiveness Analysis of the Media and Content Industries: the Book Publishing Industry, JRC Technical Reports, European Commission. 
Sotarauta M., Srinivas S. (2005), “The Co-Evolution of Policy and Economic Development: A Discussion on Innovative Regions", MIT IPC Local Innovation Systems Working Paper, MIT-IPC-LIS-05-001, 48p.

Swann P. (2010), "The economics of standardization: an update", Report for the UK Department of Business, Innovation and Skills (BIS), Innovative Economics Limited, pp. 1-83.

Teece D. J. (2010), "Business Models, Business Strategy and Innovation”, Long Range Planning, vol. 43, pp. 172194.

Teece, D. J., Pisano, G. and Shuen, A. (1997), "Dynamic capabilities and strategic management", Strategic Management Journal, vol. 18, pp. 509-533.

Thomke S.H. (1998), "Managing experimentation in the design of new products", Management Science, vol. 44, n. 6, p. 743-762.

Tran S. (2014), «Quelle contribution des technologies collaboratives à la configuration des organisations ?», Systèmes d'Information et Management, vol. 19, n. 2, pp. 1-31.

Tyre M., Orlikowski W.J. (1994), "Windows of opportunity: Temporal patterns of technological adaptation in organizations”, Organization Science, vol. 5, pp. 98-118.

Vitari C., Ravarini A. (2009), "A longitudinal analysis of trajectory changes in the software industry: the case of the content management application segment", European Journal of Information Systems, vol. 18, pp. 249263.

Volberda H. W, Lewin A.Y. (2003), “Guest editors' introduction - Coevolutionary dynamics within and between firms: From evolution to co-evolution”, Journal of management studies, Vol 40, No 8, pp. 2111-2136.

Von Hippel E. (2005), "Democratizing innovation", Cambridge, Mass.: The MIT Press.

Yami S., Castaldo S., Dagnino G. B., Le Roy F. (2010), Coopetition: winning strategies for the 21st century, Cheltenham, Edward Elgar.

Yu D., Hang C. C. (2010), “A reflective review of disruptive innovation theory”, International Journal of Management Reviews, vol. 12, pp. 435-452.

\section{Appendices}

\section{Appendix A: Positioning of the main companies in the e-reader market (market share,} data updated at the end of 2010)

Top 5 Vendors, Worldwide eReader Shipments, Third Quarter 2010

\begin{tabular}{llcc} 
Rank & Vendor & $3 \mathrm{Q} 10$ Shipments (M) & Market Share (\%) \\
\hline 1 & Amazon & 1.14 & $41.5 \%$ \\
\hline 2 & Pandigital & 0.44 & $16.1 \%$ \\
\hline 3 & Barnes and Noble & 0.42 & $15.4 \%$ \\
\hline 4 & Sony & 0.23 & $8.4 \%$ \\
\hline 4 & Hanvon & 0.23 & $8.2 \%$ \\
\hline 6 & Others & 0.29 & $10.4 \%$ \\
\hline
\end{tabular}

Source: IDC Worldwide Quarterly Media Tablet and eReader Tracker, January 18, 2011.

From http://www.zdnet.com/article/apples-ipad-represents-90-percent-of-all-tablets-shipped-amazon-owns-ereaders/ (Last accessed: February 2015)

\section{Appendix B: Main innovation technologies introduced by e-reader producers (analysis focused on Kindle, Kobo, and Nook e-readers; updated to January 2013)}

\begin{tabular}{|l|l|l} 
Technology name & Adopted by & Technology characteristics
\end{tabular}




\begin{tabular}{|c|c|c|}
\hline \multicolumn{3}{|r|}{ INK AND DISPLAY } \\
\hline e-ink & $\begin{array}{l}\text { Kindle } 1 \text { (2007), } \\
\text { Kindle 2 (2009), } \\
\text { Kobo wireless } \\
\text { (2010), Nook } \\
\text { classic (2009) }\end{array}$ & $\begin{array}{l}\text { E-Ink (electrophoretic ink) is a specific proprietary type of electronic } \\
\text { paper manufactured by E Ink Corporation, founded in 1997. It is based } \\
\text { on research started at the MIT Media Lab. }\end{array}$ \\
\hline VIZPLEX & $\begin{array}{l}\text { Nook classic } \\
(2009)\end{array}$ & $\begin{array}{l}\text { E-Ink Vizplex is the internal name of E-Ink's current line of display } \\
\text { technologies. }\end{array}$ \\
\hline e-ink pearl & \begin{tabular}{|l} 
Kindle DX \\
(2009), Kindle 3 \\
(2010), Kindle 4 \\
(2011), Kindle \\
Touch (2011), \\
Nook Simple \\
Touch (2011, \\
2012), Kobo \\
Touch (2011), \\
Kobo Mini \\
\end{tabular} & $\begin{array}{l}\text { E-Ink Pearl, which was announced on July } 31,2010 \text {, is the second } \\
\text { generation of E-Ink Vizplex displays, which offer a higher contrast } \\
\text { screen built with E-Ink Pearl Imaging Film. }\end{array}$ \\
\hline Accelerometer & $\begin{array}{l}\text { Kindle DX } \\
(2009)\end{array}$ & $\begin{array}{l}\text { This technology can automatically rotate the page display according } \\
\text { to the orientation of the device. The device can sense its orientation } \\
\text { with Accelerometer and automatically rotate the page. }\end{array}$ \\
\hline $\begin{array}{l}\text { IPS (In-Place } \\
\text { Switching) screen } \\
\text { technology }\end{array}$ & Kobo Arc (2012) & $\begin{array}{l}\text { An industry-leading display optimized for 178-degree viewing angles } \\
\text { and ultra-durable glass that is resistant to damage, scratches, bumps, } \\
\text { and drops. }\end{array}$ \\
\hline SimpleTurn & $\begin{array}{l}\text { Kobo Glo, Kobo } \\
\text { Mini }\end{array}$ & $\begin{array}{l}\text { This technology makes it easy to flip between pages and jump between } \\
\text { chapters. }\end{array}$ \\
\hline MIMO wireless & $\begin{array}{l}\text { Kindle Fire } \\
(2012)\end{array}$ & $\begin{array}{l}\text { This technology can give users a strong wireless signal even if there } \\
\text { are objects between them and a Wi-Fi router. }\end{array}$ \\
\hline Tap-to-zoom & $\begin{array}{l}\text { Kindle Touch } \\
(2011), \text { Kindle } \\
\text { Paperwhite } \\
(2012) \\
\end{array}$ & $\begin{array}{l}\text { This is a dual-touch technology including pinch to zoom when reading } \\
\text { Adobe PDF documents. The text automatically adjusts and the e- } \\
\text { reader offers up a window with eight different font sizes. }\end{array}$ \\
\hline Best-Text & $\begin{array}{l}\text { Nook Simple } \\
\text { Touch (2011, } \\
\text { 2012) }\end{array}$ & $\begin{array}{l}\text { This technology optimizes each letter for ultra-crisp words and } \\
\text { produces super-sharp fonts. }\end{array}$ \\
\hline zForce & $\begin{array}{l}\text { Kobo Touch } \\
\text { (2011), Kindle } \\
\text { Touch }(2011) \text {, } \\
\text { Nook Simple } \\
\text { Touch }(2011, \\
\text { 2012) } \\
\end{array}$ & $\begin{array}{l}\text { The screen itself does not register any touches. Instead, sensors along } \\
\text { the screen edges can track a finger that touches the standard e-ink } \\
\text { screen and interpret that data as a touch point. There are small infrared } \\
\text { areas built around the side of the bezel that allow for measurement of } \\
\text { intensity of touch when interacting with the touchscreen. }\end{array}$ \\
\hline \multicolumn{3}{|c|}{$\begin{array}{l}\text { LIGHT AND QUALITY IMAGE } \\
\end{array}$} \\
\hline Light Guide & $\begin{array}{l}\text { Kindle } \\
\text { Paperwhite } \\
\text { (2012) }\end{array}$ & $\begin{array}{l}\text { This technology offers built-in illumination for low light and dark } \\
\text { conditions. "The technology did not exist to build a display with this } \\
\text { level of contrast, resolution, brightness and battery life, so our } \\
\text { engineers invented it", said CEO Jeff Bezos. Amazon's light-guide } \\
\text { technology precisely diffuses the light across the screen and only } \\
\text { requires four LEDs to light the entire screen (unlike LCD screens, } \\
\text { which can use up to 50 LEDs). }\end{array}$ \\
\hline Glowlight & $\begin{array}{l}\text { Nook Simple } \\
\text { Touch (2012) }\end{array}$ & $\begin{array}{l}\text { Built-in LED lights called "Glowlight" technology make reading in the } \\
\text { dark easier. The Glowlight is a front-lighting technology that uses a } \\
\text { diffraction grating technique to diffuse light across the screen. }\end{array}$ \\
\hline ComfortLight & Kobo Glo & $\begin{array}{l}\text { Some LEDs are put between the frame and the screen, which removes } \\
\text { glare. }\end{array}$ \\
\hline
\end{tabular}




\begin{tabular}{|c|c|c|}
\hline $\begin{array}{l}\text { Advanced True } \\
\text { Wide Polarizing } \\
\text { Filter }\end{array}$ & $\begin{array}{l}\text { Kindle Fire } \\
(2011,2012)\end{array}$ & $\begin{array}{l}\text { This technology allows the tablet's screen to show the full color } \\
\text { spectrum from any angle. The result is a } 25 \% \text { reduction in flashing. }\end{array}$ \\
\hline VividView & $\begin{array}{l}\text { Nook Simple } \\
\text { Touch }(2011, \\
\text { 2012), Nook } \\
\text { color }(2010)\end{array}$ & $\begin{array}{l}\text { This technology is used to enhance image quality when viewing in } \\
\text { direct sunlight. }\end{array}$ \\
\hline \multicolumn{3}{|r|}{ SOUND } \\
\hline Dolby Digital Plus & $\begin{array}{l}\text { Kindle Fire } \\
(2012)\end{array}$ & This technology makes a significant difference in sound quality. \\
\hline SIS technology & Kobo Arc (2012) & $\begin{array}{l}\text { Two front-facing stereo speakers use this technology, which enhances } \\
\text { the tablet's audio capabilities. }\end{array}$ \\
\hline \multicolumn{3}{|r|}{ AUGMENTED E-BOOKS } \\
\hline Reading Life & $\begin{array}{l}\text { Kobo Touch } \\
(2011)\end{array}$ & This technology tracks reading statistics. \\
\hline X-Ray for books & $\begin{array}{l}\text { Kindle Touch } \\
(2011), \text { Kindle } \\
\text { Paperwhite } \\
(2012)\end{array}$ & $\begin{array}{l}\text { Clicking on this program will bring up a list of proper names, } \\
\text { including characters, historical figures and places. This enables the } \\
\text { reader to know how often a name appears in the book, with a list that } \\
\text { is viewable by page, chapter and full text. Clicking on a character } \\
\text { name will bring up a biography. }\end{array}$ \\
\hline X-Ray for movies & $\begin{array}{l}\text { Kindle Fire HD } \\
(2012)\end{array}$ & $\begin{array}{l}\text { A feature that uses the Internet Movie Database (IMDB) to name the } \\
\text { actors for the reader. More information about films is available. }\end{array}$ \\
\hline TypeGenius & $\begin{array}{l}\text { Kobo Glo, Kobo } \\
\text { Mini }\end{array}$ & $\begin{array}{l}\text { This technology leaves more ink on the screen so that words appear } \\
\text { sharper and crisper. A choice of } 7 \text { additional font styles and } 24 \text { sizes, } \\
\text { adjustable weight and sharpness settings, and the power to set margins } \\
\text { are also available. }\end{array}$ \\
\hline Kobo Picks & $\begin{array}{l}\text { Kobo Glo, Kobo } \\
\text { Mini }\end{array}$ & $\begin{array}{l}\text { This technology offers intuitive predictive search. Based on the } \\
\text { reader's preferences and feedback, it makes personalized e-book } \\
\text { recommendations and offers previews. }\end{array}$ \\
\hline Tapestry & Kobo Arc (2012) & $\begin{array}{l}\text { This technology allows the user to get supplementary information on } \\
\text { a purchased book. }\end{array}$ \\
\hline Kobo Pulse & $\begin{array}{l}\text { Kobo Arc } \\
(2012), \text { Kobo } \\
\text { Vox }(2011)\end{array}$ & $\begin{array}{l}\text { This technology allows the user to see how many people are reading } \\
\text { the same book and to chat with other readers. It has a function that } \\
\text { allows spoilers to be turned off. The company has also undertaken } \\
\text { various test projects in which authors talk with readers in real time. }\end{array}$ \\
\hline Kobo Writing Life & Kobo Arc (2012) & $\begin{array}{l}\text { This is a self-publishing program. Authors can publish in all of the } \\
\text { countries in which Kobo has a presence, and the program allows the } \\
\text { authors to set the prices in the different markets. They can track their } \\
\text { sales in real time. }\end{array}$ \\
\hline
\end{tabular}

